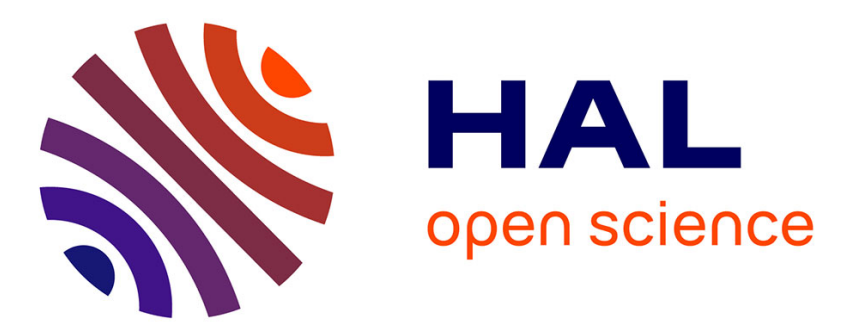

\title{
Direct and one-pot conversion of polyguluronates and alginates into alkyl-L-guluronamide-based surfactant compositions
}

\author{
N. Sari-Chmayssem, F. Pessel, Jean-Paul Guégan, S. Taha, H. Mawlawi, \\ Thierry Benvegnu
}

\section{To cite this version:}

N. Sari-Chmayssem, F. Pessel, Jean-Paul Guégan, S. Taha, H. Mawlawi, et al.. Direct and one-pot conversion of polyguluronates and alginates into alkyl-L-guluronamide-based surfactant compositions. Green Chemistry, 2016, 18 (24), pp.6573-6585. 10.1039/c6gc01983h . hal-01438116

HAL Id: hal-01438116

https://hal-univ-rennes1.archives-ouvertes.fr/hal-01438116

Submitted on 16 Mar 2017

HAL is a multi-disciplinary open access archive for the deposit and dissemination of scientific research documents, whether they are published or not. The documents may come from teaching and research institutions in France or abroad, or from public or private research centers.
L'archive ouverte pluridisciplinaire HAL, est destinée au dépôt et à la diffusion de documents scientifiques de niveau recherche, publiés ou non, émanant des établissements d'enseignement et de recherche français ou étrangers, des laboratoires publics ou privés. 


\title{
Direct and one-pot conversion of polyguluronates and alginates into alkyl-L-guluronamide-based surfactant compositions
}

\author{
N. Sari-Chmayssem, ${ }^{a, b, c}$ F. Pessel, ${ }^{a, b}$ J. P. Guégan, ${ }^{a, b}$ S. Taha, ${ }^{c}$ H. Mawlawi, ${ }^{c}$ and T. \\ Benvegnu*a,b
}

\begin{abstract}
We describe here an efficient one-pot process for the synthesis of $100 \%$ bio-based L-guluronic acid based surfactant compositions as emulsion stabilizers, directly from L-polyguluronate or whole alginate, a renewable polysaccharide extracted from brown seaweeds. The transformation of these polymers into long-chain alkyl---guluronamides associated with D-mannuronamides when alginate was used, has been achieved through the prepararation of $n$-butyl uronate monosaccharide intermediates involving methane sulfonic acic-promoted hydrolysis, Fisher glycosylation and esterification reactions, followed by in situ solvent-free aminolysis reaction with fatty amines.
\end{abstract}

\section{Introduction}

Sugar-based surfactants are an important class of amphiphilic compounds that include esters (sorbitan esters, sucrose esters), alkylpolyglycosides and amides (alkyl glucamides) widely present in the market. ${ }^{1}$ This family of bio-based surfactants gain increasing attention due to their advantages with regard to performance, health of consumers and environmental compatibility compared to other products derived from petrochemicals. ${ }^{1}$

Amide-sugar derivatives, characterized by the presence of an amide function linking hydrophilic sugar head group to lipophilic tail, are further advantageous in that they are resistant toward the hydrolysis in neutral and alkaline media, particularly compared to the ester derivatives. ${ }^{2}$ Industrially, alkyl sucroamides are produced in two steps: reductive amination of a carbohydrate with an alkylamine, followed by an acylation of the resulting $\mathrm{N}$-glycoside. ${ }^{3-5}$ Similarly, gluconamides are obtained in two steps: the oxidation of a carbohydrate leading to a lactone or aldonic acid followed by a reaction with an alkylamine to form gluconamides. ${ }^{6}$

\footnotetext{
a. Ecole Nationale Supérieure de Chimie de Rennes, CNRS, UMR 6226, 11 allée de Beaulieu, CS 50837, 35708 Rennes Cedex 7, France. E-mail:

thierry.benvegnu@ensc-rennes.fr

${ }^{b}$ Université Bretagne Loire, France.

c. Laboratory of Applied Biotechnology, AZM Center for Research in Biotechnology and its Applications, Doctoral School for Sciences and Technology, Lebanese University, Tripoli, Lebanon.

d. Electronic Supplementary Information (ESI) available: Supplementary data include ${ }^{1} \mathrm{H} N \mathrm{NR},{ }^{13} \mathrm{C}$ (JMod) of guluronate monomers 1-3 and fractions enriched in $\alpha$ or $\beta$ furanosides or pyranosides in the D-mannuronamide or L-guluronamide series, isolated after silica gel column chromatography of the GuIC $\mathbf{H}_{412}, \mathbf{G u I C}_{4} \mathbf{N}_{18}$ $\mathrm{AlgC}_{4} \mathrm{~N}_{12}$ and $\mathrm{Alg} \mathrm{C}_{4} \mathrm{~N}_{18}$ compositions.
}

Compounds containing an amide linkage between hydrophilic and lipophilic moieties ( $N$-glycoside linkage) have been recently developed. ${ }^{7}$ Another strategy was based on the formation of $\mathrm{N}$-alkylamide surfactants from uronic acids, such as glucuronic and galacturonic acids issued from the hydrolysis of hemicellulose and pectins. ${ }^{2 a}$ All the processes proposed for the preparation of these surfactants use monosaccharides as raw materials and generally the chemical reaction conditions are not eco-friendly (use of toxic and non-biodegradable reagents).

Mannuronamide surfactants were produced from Dmannuronic acid oligomers. ${ }^{2 b, c}$ The method relies on the production of oligomannuronates (after acidic depolymerization of alginate) which are then converted into monosaccharide intermediate having two butyl chains. This intermediate is then subjected to an aminolysis reaction with a fatty amine using methanol or isopropanol as a solvent, in presence or absence of organic base. The $N$-acyl derivative thus obtained exhibited emulsifying properties. Nevertheless, the use of poly(oligo)mers based on L-guluronic acid obtained after the depolymerization of alginates or the whole alginate has not been described to date.

Therefore, there is a real need for a new synthetic method to produce compounds and compositions which overcome the defects, disadvantages and obstacles of the prior art, especially for a process allowing the control of industrial scaleup, the reduction of costs and the improvement of the expected properties of compounds and compositions, particularly in the field of surfactants.

Within this context, the first objective of this work was to develop original amide monosaccharide surfactant compositions according to new specifications: (1) by implementing a methodology which transforms L-guluronic 
acid from polyguluronates or both the L-guluronic acid and Dmannuronic acid, the two uronic sugars forming alginate, into surfactant compositions composed of either exclusive Lguluronic acid or the two L-guluronic and D-mannuronic acids; 2) by developing conditions to prevent the prior step of acidic depolymerization of alginates and therefore using directly alginates as raw materials; 3) by proposing eco-friendly conditions which satisfy the principles of blue chemistry (corresponding to the concept of green chemistry applied to raw materials of marine origin), for example organic solventfree reactions, without production of waste and using biodegradable reagents; 4) by carrying out all reactions in a "one-pot" process without requiring the isolation and the purification of reaction intermediates; 5) by adjusting the amount of fatty amines used in order to get surfactant compositions characterized by the presence of controlled proportions of fatty alkyl ammonium salts; 6 ) by using simple conditions for the partial purification of the crude reaction mixture and for the isolation of monosaccharide surfactants in order to obtain compositions with competitive prices compared to those of the current market.

In this paper, the synthetic approaches for the preparation of original monosaccharide surfactant compositions are described involving a series of environmentally friendly "one pot" chemical transformations of polyguluronates or alginates of marine origin, based on hydrolysis/ glycosidation/ esterification/ aminolysis reactions. Conversions of cellulose ${ }^{8}$ or xylan $^{9}$ into biodegradable surfactants were recently reported, but to our knowledge no example of one-pot transformation of alginate into uronamide surfactants was described in the literature. Preliminary studies of these monosaccharide uromanide surfactants clearly revealed their interest as emulsion stabilizers for applications in cosmetics.

\section{Results and discussion}

Chemical transformation of L-polyguluronates into Lguluronamide surfactants

In the first stage of the work, the reactivity of sodium Lpolyguluronates obtained by the controlled acid hydrolysis of alginates $^{10}$ was investigated towards acid hydrolysis, esterification and Fisher glycosidation conditions. The objective was to expand the scope of the methodology developed in our laboratory for the direct conversion of polymannuronates to monomeric $n$-alkyl ( $n$-alkyl $\alpha$-Dmannopyranosiduronate) ${ }^{2 \mathrm{~b}, \mathrm{c}}$ to polyguluronates. Acid treatment of sodium polyguluronates $(7500 \mathrm{~g} / \mathrm{mol}$, DP $=44)$ was performed with readily biodegradable methane sulfonic acid (MSA, $n^{\prime}$ equiv.) in the presence of water (500 equiv.) and butanol (BuOH, $n$ equiv.) used as both nucleophilic reagent and solvent. The solvent was distilled out during heating and the water initially added in the reaction mixture and formed during the reaction was eliminated through the use of a DeanStark apparatus. A variety of reaction conditions in terms of $\mathrm{BuOH}$ and MSA quantities used, temperature and reaction time was envisaged (Table 1). After the work-up, the formation of three $n$-butyl L-guluronate monosaccharide derivatives generally as anomeric mixtures (Fig 1): $n$-butyl $\alpha, \beta$-Lgulofuranosidurono-6,3-lactone $1 \boldsymbol{\alpha}, \boldsymbol{\beta}, \quad(n$-butyl) $n$-butyl $\beta$-Lgulofuranosiduronate $\mathbf{2} \beta$ and (n-butyl) $n$-butyl $\alpha, \beta$-Lgulopyranosiduronate $3 \alpha, \beta$ were observed.

Table 1. Yield of the production of butyl guluronate monomers, depending on various reaction conditions, $\mathrm{BuOH}$ and MSA quantities used, temperature and reaction time $\left(\mathrm{H}_{2} \mathrm{O}: 500\right.$ equiv.).

\begin{tabular}{|c|c|c|c|c|c|}
\hline Entries & $\begin{array}{c}\text { BuOH } \\
\text { (n equiv.) }\end{array}$ & $\begin{array}{c}\text { MSA } \\
\text { ( } \mathrm{n}^{\prime} \text { equiv.) }\end{array}$ & $\begin{array}{c}\text { Temp. } \\
\left({ }^{\circ} \mathrm{C}\right)\end{array}$ & $\begin{array}{c}\mathrm{t} \\
(\mathrm{h})\end{array}$ & $\begin{array}{c}\text { Yield* } \\
(\%)\end{array}$ \\
\hline $\mathbf{1}$ & 100 & 2.5 & 80 & 48 & 9 \\
\hline $\mathbf{2}$ & 100 & 3 & 90 & 48 & 12 \\
\hline $\mathbf{3}$ & 150 & 1.8 & 110 & 12 & 23 \\
\hline $\mathbf{4}$ & 150 & 1.8 & $130-135$ & 12 & 27 \\
\hline $\mathbf{5}$ & 150 & 2.1 & $130-135$ & 12 & 36 \\
\hline $\mathbf{6}$ & 150 & 4.7 & $130-135$ & 7 & 42 \\
\hline
\end{tabular}

*mixtures of lactones $\mathbf{1} \boldsymbol{\alpha}, \boldsymbol{\beta}$, furanoside $\mathbf{2} \boldsymbol{\beta}$ and pyranosides $3 \boldsymbol{\alpha}, \boldsymbol{\beta}$ isolated after column chromatography purification.

${ }^{1} \mathrm{H}$ and ${ }^{13} \mathrm{C}$ NMR analysis coupled with additional 2D-NMR experiments (COSY, HSQC, HMBC) allowed the assignment of anomeric protons and carbons-13 for all these guluronate monomers (Table 2). In particular, 2D-HMBC clearly highlighted the presence of the furanose isomers (ester and/or lactone) and pyranoses. Indeed, this experiment contributed to determine the correlation between proton- 1 and carbon-4 (or vice-versa) which was indicative of furanose forms, and between proton- 1 and carbon-5 (or vice-versa) which proved the presence of pyranose

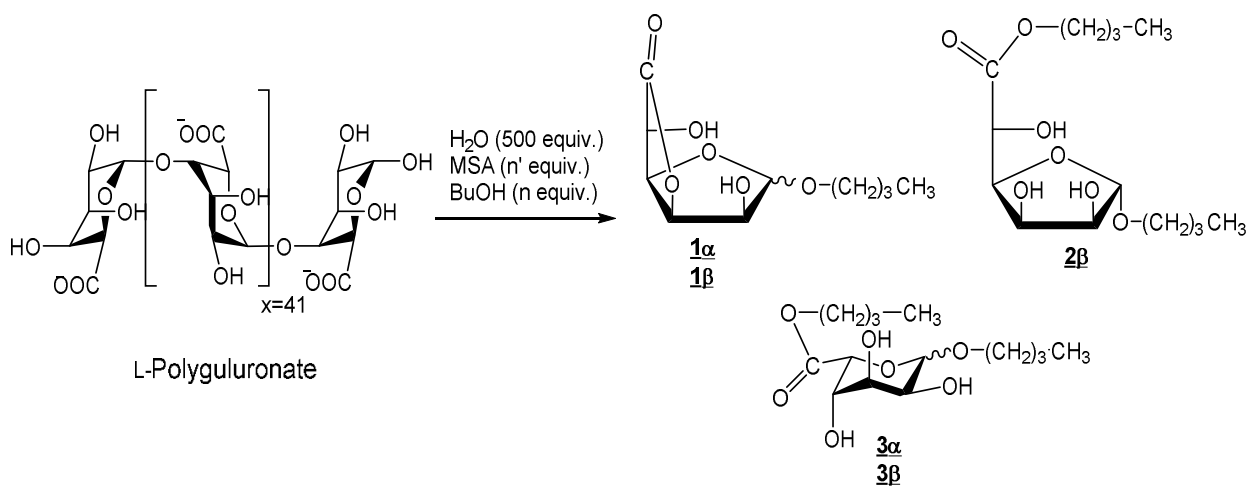

Fig. 1 Transformation of L-polyguluronate into $n$-butyl L-guluronate monosaccharide derivatives 1-3. 
isomers. Lactones were identified through the correlation between proton- 3 and carbon- 6 (or vice-versa). The chemical shifts observed were comparable to the values found for $n$-methyl $\alpha, \beta-\mathrm{L}-$ gulofuranurono-6,3-lactone ${ }^{11}$ and $n$-methyl $\alpha, \beta$-Lgulopyranosiduronate ${ }^{12}$. The different isomers were not separable by standard column chromatography purification and their relative proportion was not determined due to the complexity of NMR data analysis (see ESI, Fig.1). Consequently, the reaction yield was evaluated from the molecular weight of the guluronate unit (175.37 g.mol ${ }^{-1}$ ) of the starting polyguluronate material by considering the total amount of these inseparable isomers: the value calculated was slightly under-estimated since the molecular weight of lactone $1 \alpha, \beta$ (232.23 $\mathrm{g} \cdot \mathrm{mol}^{-1}$ ) was considered as identical to that of dibutyl compounds $\mathbf{2} \boldsymbol{\beta}$ and $\mathbf{3} \boldsymbol{\alpha}, \boldsymbol{\beta}\left(306.36 \mathrm{~g} \cdot \mathrm{mol}^{-1}\right)$. An increase of the yield was observed in refluxing $\mathrm{BuOH}$ (Table 1, entries 4-6) with increasing amounts of both $\mathrm{BuOH}$ and MSA. The use of a large excess of MSA (4.7 equiv., entry 6 ) for $7 \mathrm{~h}$ did not give a significant improvement of the yield. A longer reaction time led to lower yields due to the formation of unidentified degradation products. Thus, with the aim of minimizing the amount of base required for the neutralization of the acid in excess before the aminolysis reaction with the fatty amine, the conditions corresponding to entry 5 were selected for the next steps of the study.

Table 2. ${ }^{1} \mathrm{H}$ and ${ }^{13} \mathrm{C}$ NMR characteristics $\left(\mathrm{CDCl}_{3}\right)$ of anomeric protons and carbons for the lactone, furanose and pyranose guluronate monomers 1-3.

\begin{tabular}{|c|c|c|c|c|l|}
\hline Compounds & $\begin{array}{c}\delta \mathrm{H}_{1}(\mathrm{ppm}) \\
(\text { multiplicity) }\end{array}$ & $\begin{array}{c}\mathrm{J}_{1,2} \\
(\mathrm{~Hz})\end{array}$ & $\begin{array}{c}\delta \mathrm{C}_{1} \\
(\mathrm{ppm})\end{array}$ & $\begin{array}{c}2 \mathrm{D}-\mathrm{HMBC} \\
\text { correlation }\end{array}$ & Form \\
\hline $\mathbf{1} \boldsymbol{\alpha}$ & $4.95(\mathrm{~d})$ & 4.5 & 101.46 & $\mathrm{C}_{6}-\mathrm{H}_{3}$ & $\alpha$-lactone \\
\hline $\mathbf{1} \boldsymbol{\beta}$ & $5.06(\mathrm{~s})$ & - & 108.20 & $\mathrm{C}_{6}-\mathrm{H}_{3}$ & $\beta$-lactone \\
\hline $\mathbf{2} \boldsymbol{\beta}$ & $4.92(\mathrm{~s})$ & - & 106.21 & $\mathrm{C}_{1}-\mathrm{H}_{4}$ & $\beta$-furanose \\
\hline $\mathbf{3} \boldsymbol{\alpha}$ & $4.96(\mathrm{~d})$ & 4.1 & 100.27 & $\mathrm{C}_{1}-\mathrm{H}_{5}$ & $\alpha$-pyranose \\
\hline $\mathbf{3} \boldsymbol{\beta}$ & $4.64(\mathrm{~d})$ & 7.9 & 100.90 & $\mathrm{C}_{1}-\mathrm{H}_{5}$ & $\beta$-pyranose \\
\hline
\end{tabular}

Next, seeing the possible transformation of polyguluronates into monomeric derivatives, the same conditions were reproduced and the reaction mixture containing the butyl ester glycoside products 1-3 was subjected directly to an aminolysis reaction with a fatty dodecyl or octadecyl amine. An excess of fatty amine ( 3 equiv.) was used to ensure both neutralization of MSA and nucleophilic addition to ester/lactone electrophilic carbons. The reaction was carried out at $65^{\circ} \mathrm{C}$ to make the fatty amine liquid and under reduced pressure (6 mbar) to eliminate the butanol initially added and formed all through the aminolysis reaction. After $1.5 \mathrm{hrs}$ reaction time, ammonium salts resulting from the protonation of fatty amines and unreacted sugars were removed by washings of the crude residue with diethyl ether. The filtrate was concentrated under vacuum and the resulting crude oil was purified by silica gel column chromatography (eluent $\mathrm{CH}_{2} \mathrm{Cl}_{2} / \mathrm{CH}_{3} \mathrm{OH} 95 / 5 \mathrm{v} / \mathrm{v}$ ) to provide L-guluronamides named GulC $_{4} \mathbf{N}_{12}$ (dodecylamine $C_{12}$ series, $M_{w}=417.59 \mathrm{~g} \cdot \mathrm{mol}^{-1}$ ) or GulC ${ }_{4} N_{18}$ (octadecylamine $C_{18}$ series, $M_{w}=501.75$ g.mol ${ }^{-1}$ ), under furanose $\mathbf{4} \boldsymbol{\alpha}, \boldsymbol{\beta}\left(\mathrm{C}_{12}\right)$ or $\mathbf{5} \boldsymbol{\alpha}, \boldsymbol{\beta}\left(\mathrm{C}_{18}\right)$ and pyranose $6 \alpha, \beta\left(C_{12}\right)$ or $7 \boldsymbol{\alpha}, \boldsymbol{\beta}\left(C_{18}\right)$ forms bearing a short butyl chain at the anomeric position and a longer alkyl $\left(\mathrm{C}_{12}\right.$ and $\left.\mathrm{C}_{18}\right)$ chain amide-linked to the sugar head. The absence of any lactone derivative $1 \alpha, \beta$ proved the quantitative conversion of this bicyclic compound into the corresponding $N$-( $n$-alkyl)- $n$-butyl $\alpha, \beta$-L-gulofuranosiduronamides $\quad 4 \alpha, \beta$ or $5 \alpha, \beta$. This chromatographic method allowed to isolate a mixture composed of all these $\alpha, \beta$-L-gulofuranosiduronamide and $\alpha, \beta$ L-gulopyranosiduronamide components, or alternatively, several fractions enriched in some furanoside and/or pyranoside isomers. ${ }^{1} \mathrm{H},{ }^{13} \mathrm{C}, 2 \mathrm{D}$ COSY, HSQC and HMBC NMR experiments from the fractions enriched in $\alpha$ or $\beta$ furanosides or pyranosides provided spectra that permitted the assignment of the signals in a simpler way compared with the spectral analysis of the mixture composed of all isomeric forms. (see ESI, Figs. 2-13). In particular, the assignment of the chemical shifts for the anomeric protons $\mathrm{H}_{1}$ and carbons $\mathrm{C}_{1}$ of all furanose and pyranose forms was achieved as reported in Table 3. Furthermore, the relative proportion of the guluronamide isomers in the mixture composed of all the guluronamide surfactant forms was quantified by integrating the ${ }^{1} \mathrm{H}$ NMR signals relative to the anomeric protons of the protons. The $\beta$-L-gulofuranosiduronamide $4 \beta$ or $5 \beta$ was found to be the major components in the isomeric mixture whereas the $\beta$-L-gulopyranosiduronamide $\mathbf{6 \beta}$ or $7 \boldsymbol{\beta}$ was present in the lowest quantity. The overall yields for the production of these alkyl-L-guluronamide-based surfactants under furanose and pyranose forms were approx. $40 \%$ which constituted a quite satisfactory result given that the significant number of chemical reactions which operated during this one-pot process.

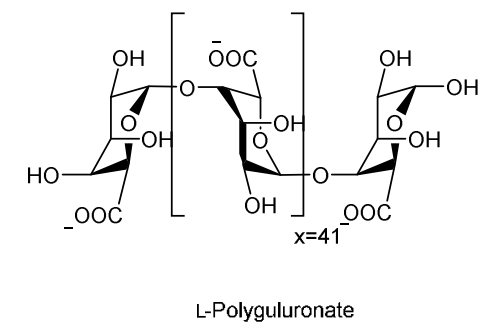

L-Polyguluronate
1) $\mathrm{H}_{2} \mathrm{O}$ (500 equiv.), MSA (2.1 equiv.) $\mathrm{BuOH}(150$ equiv.) $130-135^{\circ} \mathrm{C}, 12 \mathrm{~h}$

2) $\mathrm{H}_{3} \mathrm{C}-\left(\mathrm{CH}_{2}\right)_{n}-\mathrm{NH}_{2}$ (3 équiv.) $65^{\circ} \mathrm{C}, 1.5 \mathrm{hrs}$ $\mathrm{n}=11,40 \%$ $\mathrm{n}=17,38 \%$

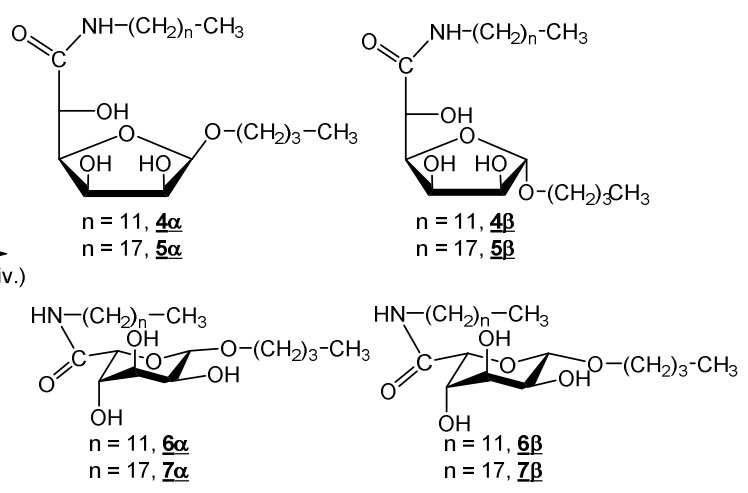

Fig. 2 Conditions used for the transformation of L-polyguluronate into L-guluronamide surfactants 4-7. 
Table 3. ${ }^{1} \mathrm{H}$ and ${ }^{13} \mathrm{C}$ NMR $\left(\mathrm{CDCl}_{3}\right)$ characteristics of anomeric protons and carbons and relative proportions for L-guluronamides $4,6\left(C_{12}\right.$ series) and $\mathbf{5 , 7}$ ( $\mathrm{C}_{18}$ series).

\begin{tabular}{|c|c|c|c|c|c|}
\hline Compounds & $\begin{array}{c}\delta \mathrm{H}_{1}(\mathrm{ppm}) \\
\text { multiplicity) }\end{array}$ & $\begin{array}{c}J_{1,2} \\
(\mathrm{~Hz})\end{array}$ & $\delta \mathrm{C}_{1}(\mathrm{ppm})$ & Form & \begin{tabular}{|c|} 
Proportion \\
$(\%)$
\end{tabular} \\
\hline \multicolumn{6}{|l|}{$\mathrm{C}_{12}$ series } \\
\hline $\begin{array}{c}4 \boldsymbol{\alpha} \\
\left(\mathrm{GulC}_{4} \mathrm{~N}_{12}\right) \\
\end{array}$ & 4.94 (d) & 4.8 & 101.51 & $\begin{array}{c}\alpha \text {-furanose } \\
(\alpha-\mathrm{L}-G \text { ulf })\end{array}$ & 21 \\
\hline $\begin{array}{c}\mathbf{4 \beta} \\
\left(\mathrm{GulC}_{4} \mathrm{~N}_{12}\right)\end{array}$ & $4.90(\mathrm{~s})$ & - & 106.36 & $\begin{array}{c}\beta \text {-furanose } \\
(\beta \text {-L-Gulf } f\end{array}$ & 37 \\
\hline $\begin{array}{c}\mathbf{6 \alpha} \\
\left(\mathrm{GulC}_{4} \mathrm{~N}_{12}\right)\end{array}$ & 4.96 (d) & 4.1 & 100.20 & $\begin{array}{c}\alpha \text {-pyranose } \\
(\alpha-\mathrm{L}-\mathrm{Gulp})\end{array}$ & 28 \\
\hline $\begin{array}{c}6 \boldsymbol{\beta} \\
\left(\mathrm{GulC}_{4} \mathrm{~N}_{12}\right)\end{array}$ & $4.64(d)$ & 8.1 & 100.98 & $\begin{array}{c}\beta \text {-pyranose } \\
(\beta \text {-ı-Gulp) }\end{array}$ & 14 \\
\hline \multicolumn{6}{|l|}{$\mathrm{C}_{18}$ series } \\
\hline $\begin{array}{c}\mathbf{5} \boldsymbol{\alpha} \\
\left(\mathrm{GulC}_{4} \mathrm{~N}_{18}\right)\end{array}$ & 4.96 (d) & 4.8 & 101.62 & $\begin{array}{c}\alpha \text {-furanose } \\
(\alpha-L-G u l f)\end{array}$ & 23 \\
\hline $\begin{array}{c}\mathbf{5} \boldsymbol{\beta} \\
\left(\text { GulC }_{4} \mathrm{~N}_{18}\right)\end{array}$ & $4.93(s)$ & - & 106.49 & $\begin{array}{c}\beta \text {-furanose } \\
(\beta \text {-L-Gulff) }\end{array}$ & 36 \\
\hline $\begin{array}{c}7 \alpha \\
\left(\mathrm{GulC}_{4} \mathrm{~N}_{18}\right)\end{array}$ & $4.97(d)$ & 4.0 & 100.23 & $\begin{array}{c}\alpha \text {-pyranose } \\
(\alpha-\mathrm{L}-\mathrm{Gulp})\end{array}$ & 25 \\
\hline $\begin{array}{c}7 \boldsymbol{\beta} \\
\left(\mathrm{GulC}_{4} \mathrm{~N}_{18}\right)\end{array}$ & $4.65(d)$ & 8.1 & 100.98 & $\begin{array}{c}\beta \text {-pyranose } \\
(\beta \text {-L-Gulp) }\end{array}$ & 16 \\
\hline
\end{tabular}

Chemical transformation of alginates into L-guluronamide and D-mannuronamide surfactant compositions

With the aim of developing a lower cost synthetic pathway for the production of uronamide-type surfactants, we then investigated a second approach based on the use of the whole sodium alginate composed of both L-guluronic acid and Dmannuronic acid $(110200 \mathrm{~g} / \mathrm{mol}, \mathrm{DP}=630, \mathrm{M} / \mathrm{G}$ ratio $=0.78) .{ }^{10}$ This challenging strategy advantageously eliminates the requirement for a preliminary step of alginate depolymerization to afford homopolymeric guluronate or mannuronate blocks as starting materials for the synthesis of our targeted surfactants. Besides, the opportunity to value both L-guluronic and D-mannuronic acids could exhibit physicochemical properties suitable for innovative cosmetic formulations. The transformation of alginate into long-chain alkyl L-guluronamide and D-mannuronamide surfactant compositions has been carried out following two routes differing only by the quantity of fatty amine used and the conditions followed for the neutralization of the acid used in the first step of the process. In each case, the first part of the synthesis involved a three-step reaction based on alginate hydrolysis, Fisher-type glycosylation and esterification of L- guluronic acid and D-mannuronic acid with butanol. Conditions similar to that described for the transformation of polyguluronates (water: 500 equiv.; butanol: 150 equiv.; 130$135^{\circ} \mathrm{C}$ ) were reproduced except for the amount of MSA and the reaction time which were increased to 2.5 equiv. and $24 \mathrm{~h}$ respectively.

Table 4. ${ }^{1} \mathrm{H}$ and ${ }^{13} \mathrm{C}$ NMR $\left(\mathrm{CDCl}_{3}\right)$ characteristics of anomeric protons and carbons and relative proportions for L-guluronamides $4,6\left(C_{12}\right.$ series) or $\mathbf{5 , 7}\left(C_{18}\right.$ series) and D-mannuronamides $\mathbf{8 , 1 0}\left(C_{12}\right.$ series $)$ or 9,11 ( $\mathrm{C}_{18}$ series).

\begin{tabular}{|c|c|c|c|c|c|}
\hline Compounds & $\begin{array}{c}\delta \mathrm{H}_{1} \text { (ppm) } \\
\text { (multiplicity) }\end{array}$ & $\begin{array}{c}J_{1,2} \\
(\mathrm{~Hz})\end{array}$ & $\delta C_{1}(p p m)$ & \begin{tabular}{|c|} 
Form \\
(uronic acid)
\end{tabular} & \begin{tabular}{|c} 
Proportion \\
$(\%)$
\end{tabular} \\
\hline \multicolumn{6}{|l|}{$C_{12}$ series } \\
\hline $\begin{array}{c}4 \boldsymbol{\alpha} \\
\left(\mathrm{AlgC}_{4} \mathrm{~N}_{12}\right)\end{array}$ & 4.97 (d) & 4.7 & 101.87 & $\begin{array}{c}\alpha \text {-furanose } \\
(\alpha-\text {-L-Gulf })\end{array}$ & 14 \\
\hline $\begin{array}{c}4 \boldsymbol{\beta} \\
\left(\mathrm{AlgC}_{4} \mathrm{~N}_{12}\right)\end{array}$ & 4.95 (s) & - & 106.52 & $\begin{array}{c}\beta \text {-furanose } \\
(\beta-\text {-L-Gulf) }\end{array}$ & 26 \\
\hline $\begin{array}{c}\mathbf{6 \alpha} \\
\left(\mathrm{AlgC}_{4} \mathrm{~N}_{12}\right)\end{array}$ & 4.96 (d) & 4.1 & 100.23 & $\begin{array}{c}\alpha \text {-pyranose } \\
(\alpha-\text {-L-Gulp) }\end{array}$ & 16 \\
\hline $\begin{array}{c}\mathbf{6 \beta} \\
\left(\mathrm{AlgC}_{4} \mathrm{~N}_{12}\right)\end{array}$ & 4.64 (d) & 8.0 & 101.04 & $\begin{array}{c}\beta \text {-pyranose } \\
(\beta \text {-L-Gulp) }\end{array}$ & 12 \\
\hline $\begin{array}{c}8 \boldsymbol{\alpha} \\
\left(\mathrm{AlgC}_{4} \mathrm{~N}_{12}\right)\end{array}$ & $4.96(\mathrm{~s})$ & - & 107.60 & $\begin{array}{c}\alpha \text {-furanose } \\
(\alpha \text {-D-Manf })\end{array}$ & 18 \\
\hline $\begin{array}{c}10 \alpha \\
\left(\mathrm{AlgC}_{4} \mathrm{~N}_{12}\right)\end{array}$ & 4.87 (d) & 1.3 & 100.08 & $\begin{array}{c}\alpha \text {-pyranose } \\
(\alpha-D-M a n p)\end{array}$ & 14 \\
\hline \multicolumn{6}{|l|}{$\mathrm{C}_{18}$ series } \\
\hline $\begin{array}{c}\mathbf{5 \alpha} \\
\left(\mathrm{AlgC}_{4} \mathrm{~N}_{18}\right)\end{array}$ & 4.96 (d) & 4.7 & 101.76 & $\begin{array}{c}\alpha \text {-furanose } \\
(\alpha-\text {-L-Gulf })\end{array}$ & 15 \\
\hline $\begin{array}{c}\mathbf{5 \beta} \\
\left(\mathrm{AlgC}_{4} \mathrm{~N}_{18}\right)\end{array}$ & $4.94(\mathrm{~s})$ & - & 106.46 & $\begin{array}{c}\beta \text {-furanose } \\
(\beta \text {-L-Gulf) }\end{array}$ & 25 \\
\hline $\begin{array}{c}7 \boldsymbol{\alpha} \\
\left(\mathrm{AlgC}_{4} \mathrm{~N}_{18}\right)\end{array}$ & 4.96 (d) & 3.5 & 100.15 & $\begin{array}{c}\alpha \text {-pyranose } \\
(\alpha-\text {-Lulp) }\end{array}$ & 16 \\
\hline $\begin{array}{c}7 \boldsymbol{\beta} \\
\left(\mathrm{AlgC}_{4} \mathrm{~N}_{18}\right)\end{array}$ & 4.64 (d) & 8.1 & 101.05 & $\begin{array}{c}\beta \text {-pyranose } \\
(\beta \text {-L-Gulp) }\end{array}$ & 12 \\
\hline $\begin{array}{c}9 \boldsymbol{\alpha} \\
\left(\mathrm{AlgC}_{4} \mathrm{~N}_{18}\right)\end{array}$ & 4.94 (s) & - & 107.42 & $\begin{array}{c}\alpha \text {-furanose } \\
(\alpha \text {-D-Manf) }\end{array}$ & 18 \\
\hline $\begin{array}{c}11 \alpha \\
\left.\left(\mathrm{AlgC}_{4} \mathrm{~N}_{18}\right)\right)\end{array}$ & 4.89 (d) & 1.5 & 100.04 & $\begin{array}{c}\alpha \text {-pyranose } \\
(\alpha-D-M a n p)\end{array}$ & 14 \\
\hline
\end{tabular}

Without previous neutralization of the medium before aminolysis reaction

Following the first step of the process that led to the formation of $n$-butyl L-guluronate and D-mannuronate intermediates, the reaction temperature was decreased to $60^{\circ} \mathrm{C}$ before adding fatty $\mathrm{C}_{12}$ or $\mathrm{C}_{18}$ amine ( 3 equiv.) without the need to further extract, purify the various $n$-butyl L-guluronate and Dmannuronate monosaccharides formed in the reaction
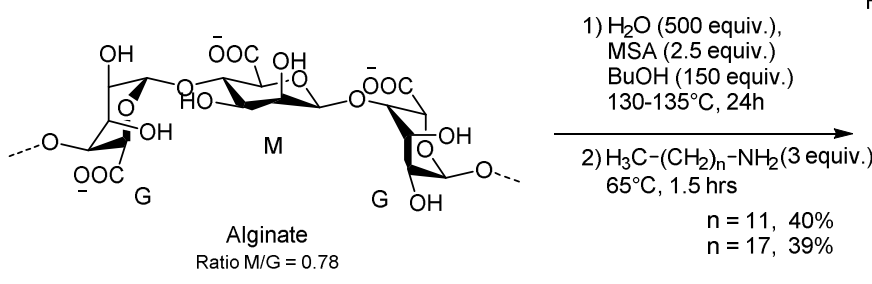

$\mathrm{n}=11,40 \%$ $\mathrm{n}=17,39 \%$
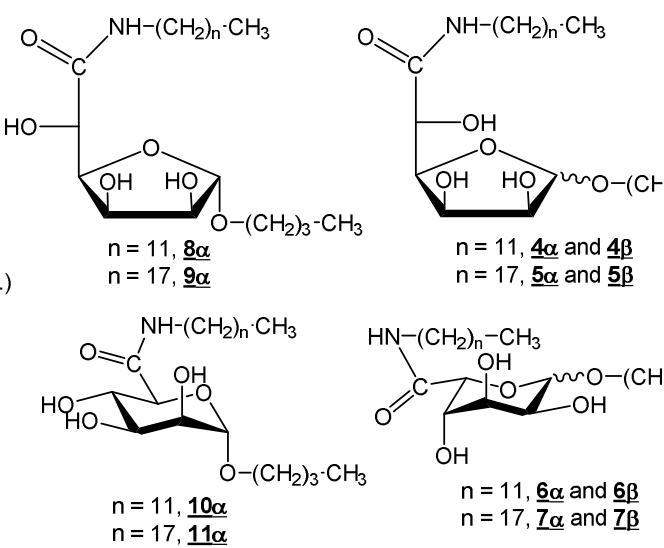

Fig. 3 Conditions used for the transformation of alginate into L-guluronamide and D-mannuronamide surfactants 4-11. 
mixture. After $1.5 \mathrm{hrs}$ reaction time at $65^{\circ} \mathrm{C}$ under reduced pressure ( $6 \mathrm{mbar}$ ) to facilitate the elimination of $n$-butanol, the residue was washed with diethyl ether in order to remove salts and unreacted sugars. Purification by silica gel chromatography furnished monosaccharide surfactant compositions named $\mathbf{A l g C}_{\mathbf{4}} \mathbf{N}_{\mathbf{1 2}}$ (dodecylamine series, $\mathrm{M}_{\mathrm{w}}=$ $417.59 \mathrm{~g} . \mathrm{mol}^{-1}$ ) and $\mathrm{AlgC}_{4} \mathbf{N}_{18}$ (octadecylamine series, $\mathrm{M}_{\mathrm{w}}=$ 501.75 g.mol ${ }^{-1}$ ), in $40 \%$ and $39 \%$ yield respectively. These compositions are composed of six isomeric forms in the Lguluronic acid and D-mannuronic acid series (Fig. 3): two $\alpha, \beta$ furanose forms $4 \alpha, \beta\left(C_{12}\right)$, or $5 \alpha, \beta\left(C_{18}\right)$ and two $\alpha, \beta$-pyranose forms $6 \alpha, \beta\left(C_{12}\right)$ or $7 \boldsymbol{\alpha}, \boldsymbol{\beta}\left(C_{18}\right)$ for $N$-(n-alkyl)-n-butyl Lguluronamides; one $\alpha$-furanose form $8 \alpha\left(C_{12}\right)$ or $9 \alpha\left(C_{18}\right)$ and its $\alpha$-pyranose isomer $10 \alpha\left(C_{12}\right)$ or $\mathbf{1 1} \alpha\left(C_{18}\right)$ for $N$-(n-alkyl)-nbutyl D-mannuronamides. As reported, ${ }^{13}$ the $1,2-c i s-\beta$-Dmannofuranosiduronamide and 1,2-cis- $\beta$-Dmannopyranosiduronamide were not formed since the formation of 1,2-cis- $\beta$-mannosides is unfavorable thermodynamically as well as kinetically owing to steric hindrance of axial 2-hydroxy group.

As for guluronamide surfactants, it was possible to obtain after silica gel column chromatography, fractions enriched in some $\alpha$ or $\beta$ furanosides or pyranosides in the $D$ mannuronamide or L-guluronamide series. Several NMR experiments $\left({ }^{1} \mathrm{H},{ }^{13} \mathrm{C}, 2 \mathrm{D}\right.$ COSY, $\mathrm{HSQC}$ and $\left.\mathrm{HMBC}\right)$ were achieved from these fractions, thus facilitating the assignment of the signals for all the isomeric forms (See ESI, Figs. 14-25).

Table 4 summarizes the main ${ }^{1} \mathrm{H}$ and ${ }^{13} \mathrm{C}$ NMR characteristics of anomeric protons and carbons in addition to the relative proportions of each isomer determined from the mixture composed of all D-mannuronamide or L-guluronamide forms, in $\mathbf{A l g C}_{4} \mathbf{N}_{12}$ and $\mathbf{A l g C}_{4} \mathbf{N}_{18}$ surfactant compositions. The $\beta$ furanoside isomer of $N$-( $n$-alkyl)- $n$-butyl L-guluronamide was found to be the predominant component whereas its $\beta$ pyranoside isomer represented the lowest proportion among all uronamide compounds in $\mathbf{A l g C}_{\mathbf{4}} \mathbf{N}_{12}$ and $\mathbf{A l g} \mathbf{C}_{\mathbf{4}} \mathbf{N}_{18}$ mixtures. Furthermore, the furanosides are dominant compared to their pyranoside counterparts for both L-guluronic acid and Dmannuronic acids.

Finally the amount of fatty ammonium salts present in the reaction mixture before the work up was evaluated from ${ }^{1} \mathrm{H}$ NMR spectrum of the crude reaction mixture by comparative integrations of the signals relative of the anomeric protons and the protons corresponding to the ammonium counter-ion $\mathrm{CH}_{3} \mathrm{SO}_{3}{ }^{-}$. Starting from $1 \mathrm{~g}$ of alginate (1 equiv.), the quantity of salt formed is about 1.8 molar equiv. for the dodecylammonium mesylate salt $(2.89 \mathrm{~g})$ and 2 molar equiv. for the octadecylammonium mesylate salt (4.16 g).

\section{With previous neutralization of the medium before aminolysis} reaction

Our attention was next directed toward the development of a novel process schematized in Fig. 4, without any final purification step, more easily transferable to an industrial scale while utilizing a lower amount of fatty amine so as to reduce the formation of ammonium salts during the aminolysis reaction. As already described, the first step of the process consisted in converting alginate into $n$-butyl L- guluronate and D-mannuronate derivatives in refluxing butanol before adjusting the temperature to $60^{\circ} \mathrm{C}$. The crude reaction mixture was then neutralized until $\mathrm{pH} 7(1 \mathrm{~N} \mathrm{NaOH})$ and partly concentrated before adding the fatty dodecyl amine (1 equiv.). The resulting mixture was stirred under progressive reduced pressure (150 to $6 \mathrm{mbar}$ ) at $65^{\circ} \mathrm{C}$ until gas evolution stopped. Water was then added and the solution was stirred at $70^{\circ} \mathrm{C}$ for $15 \mathrm{~min}$. After the stirring was stopped, the organic products flocculated and solidified at room temperature which permitted the easy removal of the salt-

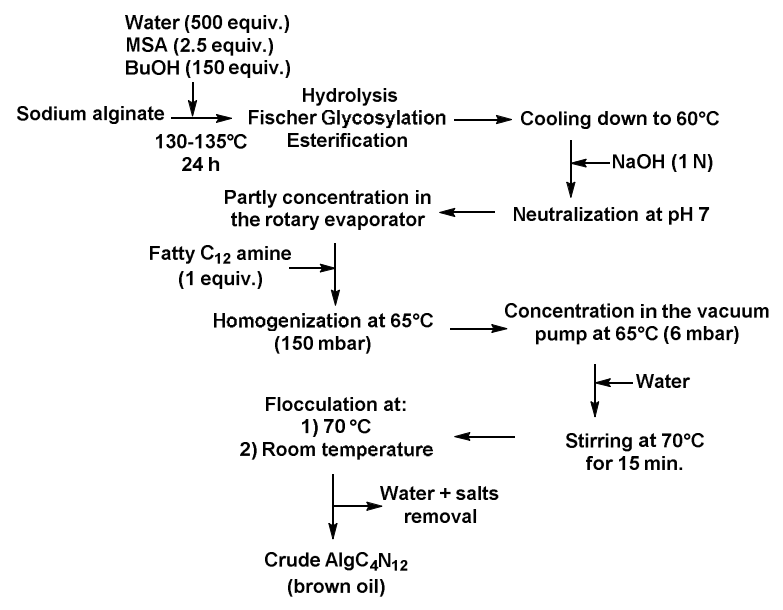

Fig.4 Synthetic process for the production of crude $\operatorname{Alg} C_{4} \mathbf{N}_{12}$.

containing aqueous phase.

The resulting brown oil named crude $\mathrm{Alg}_{4} \mathbf{N}_{12}$ (1.21 g starting from $1 \mathrm{~g}$ of alginate, see experimental part) was analyzed by $1 \mathrm{D}$ and $2 \mathrm{D}$ NMR and revealed the presence of dodecyl ammonium salt $(0.4$ equiv.; $0.64 \mathrm{~g})$ in addition to the 6 isomers of $N$-( $n$-dodecyl)- $n$-butyl L-guluronamide and $N$-( $n$-dodecyl)- $n$-butyl D-mannuronamide (Table 4). The relative proportions of the isomeric L-guluronamides and Dmannuronamides are similar to those observed for the first synthetic pathway without any previous neutralization of the reaction medium (Table 5). Conversely, the final amount of fatty ammonium salt was dramatically reduced.

This process represents a promising way of manufacturing surfactants derived from alginates without requiring the standard steps of solid-liquid separations or column chromatography purification while eliminating inorganic salts and water in a simple way. Very recently, the scale up of the synthesis was successfully achieved using a $20 \mathrm{~L}$ reactor for the production of the crude $A \lg C_{4} N_{12}$ at a $200 \mathrm{~g}$ scale. BuOH used in the process was recycled and re-used for additional production.

Preliminary evaluation of the emulsifying properties of Lguluronamide-containing surfactant compositions

The ability of the L-guluronamide-based surfactant compositions to stabilise water-in-oil (W/O) and oil-in-water (O/W) emulsions was investigated from $\mathrm{GuIC}_{\mathbf{4}} \mathbf{N}_{\mathbf{1 2}}, \mathrm{GuIC}_{\mathbf{4}} \mathbf{N}_{\mathbf{1 8}}$, $\mathrm{AlgC}_{4} \mathrm{~N}_{12}, \mathrm{AlgC}_{4} \mathrm{~N}_{18}$ and crude $A \lg \mathrm{C}_{4} \mathrm{~N}_{12}$ mixtures. 
Table 5. ${ }^{1} \mathrm{H}$ and ${ }^{13} \mathrm{C}$ NMR $\left(\mathrm{CDCl}_{3}\right)$ characteristics of anomeric protons and carbons and relative proportions for L-guluronamides 4,6 and $D$ mannuronamides $\mathbf{8 , 1 0}$ derived from dodecylamine in crude $\mathbf{A l g C}_{\mathbf{4}} \mathbf{N}_{\mathbf{1 2}}$.

\begin{tabular}{|c|c|c|c|c|c|}
\hline Compounds & $\begin{array}{c}\delta \mathrm{H}_{1}(\mathrm{ppm}) \\
\text { multiplicity) }\end{array}$ & $\begin{array}{c}J_{1,2} \\
(\mathrm{~Hz})\end{array}$ & $\delta \mathrm{C}_{1}(\mathrm{ppm})$ & $\begin{array}{c}\text { Form } \\
\text { (uronic acid) }\end{array}$ & $\begin{array}{c}\text { Proportion } \\
(\%)\end{array}$ \\
\hline $\begin{array}{c}\mathbf{4} \boldsymbol{\alpha} \\
\left.\text { (crude } \mathrm{AlgC} \mathrm{N}_{42}\right)\end{array}$ & $4.96(\mathrm{~d})$ & 4.5 & 101.76 & $\begin{array}{c}\alpha \text {-furanose } \\
(\alpha \text {-L-Gulf) }\end{array}$ & 14 \\
\hline $\begin{array}{c}\mathbf{4} \boldsymbol{\beta} \\
\text { crude } \mathrm{AlgC} \mathrm{N}_{42}\end{array}$ & $4.95(\mathrm{~s})$ & - & 106.28 & $\begin{array}{c}\beta \text {-furanose } \\
(\beta \text {-L-Gulf) }\end{array}$ & 24 \\
\hline $\begin{array}{c}\mathbf{6} \boldsymbol{\alpha} \\
\text { crude } \mathrm{AlgC}_{4} \mathrm{~N}_{12}\end{array}$ & $4.97(\mathrm{~d})$ & 4.2 & 100.39 & $\begin{array}{c}\alpha \text {-pyranose } \\
(\alpha \text {-L-Gulp) }\end{array}$ & 18 \\
\hline $\begin{array}{c}\mathbf{6} \boldsymbol{\beta} \\
\text { crude } \mathrm{AlgC}_{4} \mathrm{~N}_{12}\end{array}$ & $4.64(\mathrm{~d})$ & 8.0 & 101.41 & $\begin{array}{c}\beta \text {-pyranose } \\
(\beta \text {-L-Gulp) }\end{array}$ & 10 \\
\hline $\begin{array}{c}\mathbf{8} \boldsymbol{\alpha} \\
\text { crude } \mathrm{AlgC}_{4} \mathrm{~N}_{12}\end{array}$ & $4.94(\mathrm{~s})$ & - & 107.55 & $\begin{array}{c}\alpha \text {-furanose } \\
(\alpha \text {-D-Manf) }\end{array}$ & 19 \\
\hline $\begin{array}{c}\mathbf{1 0} \boldsymbol{\alpha} \\
\text { crude } \mathrm{AlgC}_{4} \mathrm{~N}_{12}\end{array}$ & $4.88(\mathrm{~d})$ & 1.5 & 100.04 & $\begin{array}{c}\alpha \text {-pyranose } \\
(\alpha \text {-D-Manp) }\end{array}$ & 15 \\
\hline
\end{tabular}

\section{Interfacial behaviour}

Firstly, interfacial tension measurements using sunflower oil were performed at $25^{\circ} \mathrm{C}$ with a Du Noüy ring tensiometer (K100-Krüss, Germany). The ring tear-off method used for this study is a variant of the Du Noüy ring method for measuring surface tension or interfacial tension. Instead of detecting the force maximum when the lamella is stretched, as is usual with modern tensiometers, the lamella is overstretched until it detaches. The value measured in this way deviates slightly from the actual value of the surface tension. ${ }^{14}$ Due to their water-insolubility, these surfactant compositions were dissolved in sunflower oil at concentrations varying from 0.12 to 3.49 $\mathrm{g} / \mathrm{L}$. Solutions were left in ultrasonic bath for $10 \mathrm{~min}$. at $50^{\circ} \mathrm{C}$ to make surfactant dispersions in oil easier. Similarly, uronamide surfactant compositions reduced interfacial tension to low values compatible with good emulsifying properties (Fig. 5). It is noteworthy that crude $\mathbf{A l g C} \mathbf{C}_{4} \mathbf{N}_{12}$ composed of dodecyl ammonium salt and L-guluronamide and $\mathrm{D}$-mannuronamide isomers exhibited superior interfacial properties compared to $\mathrm{AlgC}_{\mathbf{4}} \mathbf{N}_{12}$ surfactant composition isolated after an additional purification step by silica gel column chromatography. Moreover, monosaccharide compositions derived from dodecylamine GulC $\mathbf{N}_{12}, \operatorname{AlgC}_{4} \mathbf{N}_{12}$, and crude $\operatorname{AlgC}_{4} \mathbf{N}_{12}$ were found to have more attractive interfacial properties than their counterparts produced from octadecylamine GuIC $_{4} \mathbf{N}_{18}$ and $\mathrm{AlgC}_{\mathbf{4}} \mathbf{N}_{18}$. In addition, an emulsifier, named Montanov $82^{\circledR}$ from Seppic, was recently evaluated as a sugar-based surfactant reference in a water-sunflower oil system; this commercial composition exhibited good surface activities (interfacial tension values of $21.03 \mathrm{mN} \cdot \mathrm{m}^{-1}$ without any surfactant, and of $16.34 \mathrm{mN} \cdot \mathrm{m}^{-1}$ and $4.45 \mathrm{mN} \cdot \mathrm{m}^{-1}$ at a surfactant concentration of 0.13 and $0.51{\mathrm{~g} . \mathrm{L}^{-1}}^{-1}$ respectively).

\section{Emulsion stabilization}

The emulsifying properties of the various compositions were estimated both in oil-in-water (O/W) and water-in-oil (W/O) systems in comparison with those of commercial alkylpolyglycosides: : Montanov $82^{\circledR}$ from Seppic. Each emulsion was prepared at a surfactant concentration of $0.5 \%$ in weight, by considering the two water/oil ratios $75 / 25$ and $25 / 75$ respectively. The emulsion stabilizing effect of the surfactants was evaluated by determining the time required for a total demixing of the emulsion (Table 6).

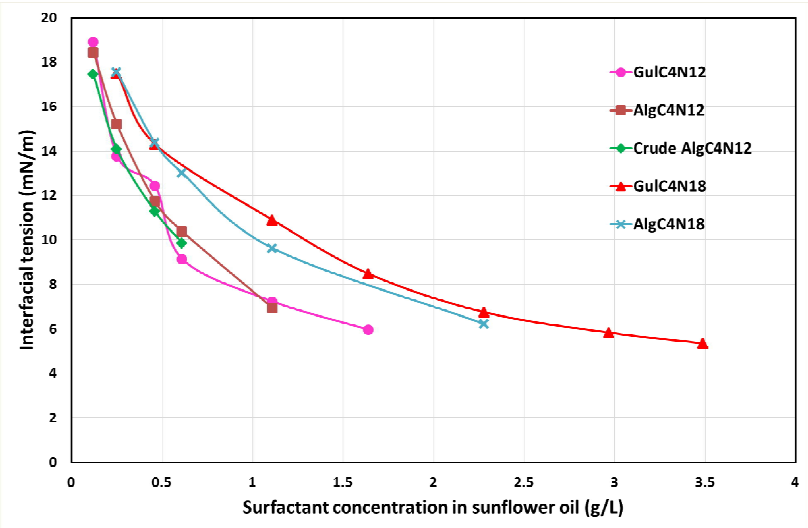

Fig 5. Interfacial tension measurements in water-sunflower oil system for different concentrations in uromanide surfactant compositions. A value comprised between 24.71 and $25.04 \mathrm{mN} . \mathrm{m}^{-1}$ was measured in the absence of any surfactant.

Among the compositions tested, $\operatorname{GuIC}_{4} \mathbf{N}_{12}, \operatorname{AlgC}_{4} \mathbf{N}_{12}$, and crude AlgC $_{4} \mathbf{N}_{12}$ engendered the highest stabilities of $\mathrm{O} / \mathrm{W}$ emulsions since the emulsions remained unchanged after at least one month at $20^{\circ} \mathrm{C}$. Faster demixing of the emulsions was observed when $\mathbf{G u I C}_{\mathbf{4}} \mathbf{N}_{\mathbf{1 8}}, \mathbf{A l g C}_{\mathbf{4}} \mathbf{N}_{\mathbf{1 8}}(<12 \mathrm{~h})$ and commercial emulsifier Montanov ${ }^{\circledast} 82(<24 \mathrm{~h})$ were used.

Stabilization of W/O emulsions was next studied in the presence of the same surfactant compositions. It was observed that all GulC $_{4} N_{18}, \quad \operatorname{AlgC}_{4} N_{18}, \quad \operatorname{GulC}_{4} N_{18}, \quad \operatorname{AlgC} \mathbf{N}_{12}, \quad \operatorname{AlgC}_{4} \mathbf{N}_{18}$ mixtures exhibited good to excellent emulsifying properties unlike crude $\mathrm{AlgC}_{4} \mathrm{~N}_{12}$ and Montanov ${ }^{\circledR} 82$ which led to more modest efficiencies as emulsion stabilizers. Further experiments are in progress to evaluate the behaviour of these new uronamide surfactant compositions in the presence of electrolytes, additional oils and in cosmetic formulations.

Table 6 . Evaluation of the emulsion stability in the presence of surfactant compositions.

\begin{tabular}{|c|c|c|}
\hline Compounds* & W/O emulsion & $\mathrm{O} / \mathrm{W}$ emulsion \\
\hline $\mathrm{GuIC}_{4} \mathrm{~N}_{12}$ & +++ & +++ \\
\hline $\mathrm{AlgC}_{4} \mathrm{~N}_{12}$ & +++ & +++ \\
\hline Crude AlgC $_{4} \mathrm{~N}_{12}$ & + & +++ \\
\hline GulC $_{4} \mathrm{~N}_{18}$ & +++ & - \\
\hline $\mathrm{AlgC}_{4} \mathrm{~N}_{18}$ & ++ & - \\
\hline Montanov $^{\circledR} 82$ & + & + \\
\hline
\end{tabular}

*Time for the total demixing of the emulsion: $-<12 \mathrm{~h} ;+<24 \mathrm{~h} ;++=7$ days; $+++>1$ month.

\section{Conclusions}

This study is the first report describing the eco-friendly conversion of sodium L-polyguluronate or alginate into novel L-guluronamidebased surfactant compositions. Direct acid hydrolysis of the polysaccharides coupled with Fischer glycosylation and esterification reaction of D-mamnuronic acid and/or L-guluronic acid with butanol proceeded efficiently in the presence of MSA 
promoter to provide the corresponding $n$-butyl uronate intermediates. Subsequent transformation of these monomannuronate and/or guluronate derivatives into long-chain alkyl Lguluronamide and D-mannuronamide surfactant mixtures has been carried out without any isolation and purification step of the intermediates through a one-pot solvent-free aminolysis reaction with fatty amines. In addition, a process based on the neutralization of MSA prior to aminolysis reaction and the use of reduced amount of fatty amine was developed to manufacture surfactants directly from alginates without requiring the standard steps of solid-liquid separations while removing simply inorganic salts and other watersoluble products. These uronamide surfactant compositions were found to exhibit promising emulsifying properties compared to other sugar-based surfactant references. Additionally, attractive antibacterial effects of these sugar-based surfactants against Gram positive bacteria were observed and they will be reported elsewhere. The study of their application in cosmetic formulations and the evaluation of alternative reaction conditions (use of heterogeneous acids and/or microwaves) are currently under investigation.

\section{Experimental section}

\section{General}

Sodium alginate $(110200 \mathrm{~g} / \mathrm{mol}, \mathrm{DP}=630, \mathrm{M} / \mathrm{G}$ ratio $=0.78)$ and sodium L-Polyguluronate $(7500 \mathrm{~g} / \mathrm{mol}, \mathrm{DP}=44)$ were extracted from brown seaweeds and depolymerized as recently described. ${ }^{10}$ All commercially available chemicals were used without further purification. Analytical TLC was performed on Merck 60 F254 silica gel nonactivated plates. A solution of $5 \% \mathrm{H}_{2} \mathrm{SO}_{4}$ in EtOH was used to develop the plates. Merck $60 \mathrm{H}(5-40 \mu \mathrm{m})$ silica gel and semi-automated systems such as Puriflash ${ }^{\circledR} 430$ Interchim equipped with UV and DEDL detector were used for column chromatography with GraceResolv silica (from 4 to $80 \mathrm{~g}$ ) or puriflash interchim (40 to $80 \mathrm{~g}, 25 \mu \mathrm{m}$ ) cartridges. Electropositive electrospray (ESI+) mass spectra were acquired on MS/MS TOF and the Shimadzu ensemble LCMS-2020 mass spectrometers, all samples were further dissolved in methanol. $1 \mathrm{D}$ and $2 \mathrm{D}$ NMR experiments for uronamide monosaccharidic surfactant were done in $\mathrm{CDCl}_{3}$. NMR spectra were recorded on a Bruker Avance III 400 spectrometer operating at $400.13 \mathrm{MHz}$ for ${ }^{1} \mathrm{H}$, equipped with a BBFO probe with a Z-gradient coil and a GREAT 1/10 gradient unit. The zg30 Bruker pulse program was used for $1 \mathrm{D}{ }^{1} \mathrm{H} N M R$, with a TD of $64 \mathrm{k}$, a relaxation delay $\mathrm{d} 1=2 \mathrm{~s}$. For the integration of each peak, the Topspin 2.1 Bruker and MestReNova 10.0.2 software were used. ${ }^{13} \mathrm{C}$ NMR spectra were recorded at 100.61 $\mathrm{MHz} .4000$ to 8000 scans were generally used with a relaxation delay of 2 seconds and an acquisition time of 1.3 seconds for a spectral width of $220 \mathrm{ppm}$ was used. Jmod or power gate were used indifferently. Fourier transform was performed after apodization with an exponential function using a $L B$ of $0.6 \mathrm{~Hz}$ to $2 \mathrm{~Hz}$. 2D COSY experiments were acquired using the cosygpdqf pulse program. Matrices consisting of 256-400 (t1) $\times$ 2048 (t2) complex data points were recorded with a $1.5 \mathrm{~s}$ recovery delay (d1) and an acquisition time of $0.25 \mathrm{~s}$, processing was performed with a QSINE function in both dimensions $(\mathrm{SSB}=0)$. For $2 \mathrm{D} \mathrm{HSQC}\left({ }^{1} \mathrm{H}^{13} \mathrm{C}\right)$ experiment, two pulse programs for high sensitivity were used with 8 to 24 scans depending on the concentration, acquisition time of 0.25 seconds and a relaxation delay about 1.5 seconds. Generally, a number of increments of 256 (t1) was acquired, Fourier transform was performed in both dimensions with a SINE function $(\mathrm{SSB}=3)$. 2D HMBC $\left({ }^{1} \mathrm{H}^{13} \mathrm{C}\right)$ was performed with either the hmbcplrndqf or the impact-hmbc pulse program. D1 was set to $0.3 \mathrm{~s}$ to $1.5 \mathrm{~s}$, delay $\mathrm{d} 6$ for the evolution of long range coupling was set to $65 \mathrm{~ms}$, the number of scans was about 32 scans and the number of series was generally 256 (t1). All the data were processed with a SINE function in both dimensions $(\mathrm{SSB}=3)$.

Synthesis of $n$-butyl L-guluronate monosaccharide derivatives. Sodium L-polyguluronate $(7500 \mathrm{~g} / \mathrm{mol}, \mathrm{DP}=44)(1$ $\mathrm{g}, 5.71 \mathrm{mmol}, 1$ equiv.) was mixed with $2 \mathrm{~mL}$ of deionized water (500 equiv.) and $778 \mu \mathrm{L}$ of methane sulfonic acid (12 mmol, 2.1 equiv.). $80 \mathrm{~mL}$ of $n$-butanol (150 equiv.) were added to the solution of polyguluronate. The reaction mixture was vigorously stirred in refluxing butanol $\left(130-135^{\circ} \mathrm{C}\right)$ for 12 hours. Water present in the medium and formed during the esterification/glycosylation reactions was progressively eliminated in a Dean Stark material filled with butanol by azeotropic evaporation $\left(\mathrm{H}_{2} \mathrm{O} / \mathrm{BuOH}\right)$. After $12 \mathrm{~h}$, the reaction mixture was allowed to cool down to room temperature, then a thin layer chromatography $\left(\mathrm{CH}_{2} \mathrm{Cl}_{2} / \mathrm{CH}_{3} \mathrm{OH} 95 / 5 \mathrm{v} / \mathrm{v}\right)$ and ${ }^{1} \mathrm{H}$ and ${ }^{13} \mathrm{C}$ NMR experiments $\left(\mathrm{CDCl}_{3}\right)$ were carried out for the medium to ensure that the expected products were synthesized. After cooling to room temperature, the mixture was neutralized with aq. $1 \mathrm{~N} \mathrm{NaOH}$ solution and concentrated under reduced pressure $\left(10 \mathrm{mbar}, 50^{\circ} \mathrm{C}\right)$. Insoluble salts were removed by washing the dry product with diethyl ether and a filtration was achieved through celite. The organic layer was concentrated and the obtained crude oil was chromatographed on silica gel column (80 g, eluent $\mathrm{CH}_{2} \mathrm{Cl}_{2} / \mathrm{CH}_{3} \mathrm{OH} 95 / 5 \mathrm{v} / \mathrm{v}$ ) to afford a mixture of three $n$-butyl Lguluronate monosaccharide derivatives, generally as anomeric mixtures, isolated as a yellow oil (624 mg, 36\%): 2 lactone forms $(232.23 \mathrm{~g} / \mathrm{mol})$ of $n$-butyl $\alpha$-L-gulofuranosidurono-6,3lactone $\underline{\mathbf{1} \alpha}$ and $n$-butyl $\beta$-L-gulofuranosidurono-6,3-lactone $\underline{\mathbf{1} \beta}$ in addition to 3 isomeric forms ( $306.36 \mathrm{~g} / \mathrm{mol}$ ) of ( $n$-butyl)- $n$ butyl- $\beta$-L-gulofuranosiduronate $\quad \underline{\mathbf{2}} \boldsymbol{\beta}, \quad(n$-butyl)- $n$-butyl- $\alpha-\mathrm{L}-$ gulopyranosiduronate $\underline{3 \alpha}$ and (n-butyl)- $n$-butyl- $\beta$-Lgulopyranosiduronate $\underline{3 \beta}$. $R f 0.59$ and $0.48\left(\mathrm{CH}_{2} \mathrm{Cl}_{2} / \mathrm{MeOH}: 9 / 1\right.$ $\mathrm{v} / \mathrm{v})$.

1 $\underline{\alpha}: \delta_{\mathrm{H}}\left(400.13 \mathrm{MHz}, \mathrm{CDCl}_{3}\right) 0.90\left(3 \mathrm{H}, \mathrm{t}, \mathrm{CH}_{3}\right), 1.26-1.36(2 \mathrm{H}, \mathrm{m}$, $\left.\mathrm{CH}_{2} \mathrm{CH}_{3}\right), 1.50-1.57\left(2 \mathrm{H}, \mathrm{m}, \mathrm{CH}_{2}\right), 3.43(1 \mathrm{H}, \mathrm{dt}, J 6.5,9.5 \mathrm{~Hz}, \mathrm{C} 1-$ O-Cㅡㅡ), $3.70\left(1 \mathrm{H}, \mathrm{dt}, J 6.5,9.5 \mathrm{~Hz}, \mathrm{C} 1-\mathrm{O}-\mathrm{CH}^{\prime}\right), 4.15(1 \mathrm{H}, \mathrm{dd}, J$ J.5, $5.5 \mathrm{~Hz}, \mathrm{H} 2), 4.27(1 \mathrm{H}, \mathrm{s}, \mathrm{H} 5), 4.69(1 \mathrm{H}, \mathrm{d}, J 5.5 \mathrm{~Hz}, \mathrm{H} 4), 4.95(1 \mathrm{H}$, d, J $4.5 \mathrm{~Hz}, \mathrm{H} 1), 4.97(1 \mathrm{H}, \mathrm{t}, J 5.5 \mathrm{~Hz}, \mathrm{H} 3) ; \delta_{\mathrm{C}}(100.61 \mathrm{MHz}$, $\left.\mathrm{CDCl}_{3}\right) 13.90\left(\mathrm{CH}_{3}\right), 19.20\left(\mathrm{C}_{2} \mathrm{CH}_{3}\right), 31.50\left(\mathrm{CH}_{2}\right), 69.40\left(\mathrm{C}_{1}-\mathrm{O}-\right.$ $\mathrm{CH}_{2}$ ), 72.90 (C2), 74.70 (C5), 78.90 (C3), 82.10 (C4), 101.46 (C1), 175.90 ( $\underline{\mathrm{COO}}(\mathrm{C} 6))$.

1ㅅ: $\delta_{\mathrm{H}}\left(400.13 \mathrm{MHz}, \mathrm{CDCl}_{3}\right) 0.91\left(3 \mathrm{H}, \mathrm{t}, \mathrm{CH}_{3}\right), 1.28-1.38(2 \mathrm{H}, \mathrm{m}$, $\left.\mathrm{CH}_{2} \mathrm{CH}_{3}\right), 1.46-1.56\left(2 \mathrm{H}, \mathrm{m}, \mathrm{CH}_{2}\right), 3.41(1 \mathrm{H}, \mathrm{dt}, J 6.5,9.5 \mathrm{~Hz}, \mathrm{C} 1-$ 
O-C브), $3.68\left(1 \mathrm{H}, \mathrm{dt}, J 6.5,9.5 \mathrm{~Hz}, \mathrm{C} 1-\mathrm{O}-\mathrm{CH}^{\prime}\right), 4.23(1 \mathrm{H}, \mathrm{d}, J 4.5$ $\mathrm{Hz}, \mathrm{H} 2), 4.58(1 \mathrm{H}, \mathrm{d}, J 4.0 \mathrm{~Hz}, \mathrm{H} 5), 4.70(1 \mathrm{H}, \mathrm{dd}, J 4.0,7.5 \mathrm{~Hz}$, $\mathrm{H} 4), 5.06(1 \mathrm{H}, \mathrm{s}, \mathrm{H} 1), 5.13(1 \mathrm{H}, \mathrm{dd}, J 4.5,7.5 \mathrm{~Hz}, \mathrm{H} 3) ; \delta_{\mathrm{C}}(100.61$ $\left.\mathrm{MHz}, \mathrm{CDCl}_{3}\right) 13.90\left(\mathrm{CH}_{3}\right), 19.30\left(\underline{\mathrm{CH}}_{2} \mathrm{CH}_{3}\right), 31.50\left(\mathrm{CH}_{2}\right), 67.80$ $\left(\mathrm{C}_{1}-\mathrm{O}-\mathrm{CH}_{2}\right), 72.40(\mathrm{C} 2), 73.90$ (C5), 79.70 (C3), 82.20 (C4), 108.20 (C1), 176.90 (ㅇO (C6)).

2ㅇ: $\delta_{\mathrm{H}}\left(400.13 \mathrm{MHz}, \mathrm{CDCl}_{3}\right) 0.86\left(3 \mathrm{H}, \mathrm{t}, \mathrm{CH}_{3}\right), 0.89\left(3 \mathrm{H}, \mathrm{t}, \mathrm{CH}_{3}\right)$, 1.23-1.25 (2H, m, $\left.\mathrm{C}_{2} \mathrm{CH}_{3}\right), 1.38-1.41\left(2 \mathrm{H}, \mathrm{m}, \mathrm{CH}_{2}\right), 1.59-1.64$ $\left(2 \mathrm{H}, \mathrm{m}, \mathrm{CH}_{2}\right), 3.34(1 \mathrm{H}, \mathrm{dt}, J 6.5,9.5 \mathrm{~Hz}, \mathrm{C} 1-\mathrm{O}-\mathrm{C} \underline{\mathrm{H}}), 3.65(1 \mathrm{H}, \mathrm{dt}$, J 6.6, $\left.9.5 \mathrm{~Hz}, \mathrm{C} 1-\mathrm{O}-\mathrm{CH}^{\prime}\right), 3.97(1 \mathrm{H}, \mathrm{d}, J 4.9 \mathrm{~Hz}, \mathrm{H} 2), 4.15(2 \mathrm{H}, \mathrm{t}, J$ $\left.6.1 \mathrm{~Hz}, \mathrm{C}_{6} \mathrm{OO}-\mathrm{CH}_{2}\right), 4.24(1 \mathrm{H}, \mathrm{d}, J 3.1 \mathrm{~Hz}, \mathrm{H} 5), 4.35(1 \mathrm{H}, \mathrm{dd}, J 3.1$, $7.2 \mathrm{~Hz}, \mathrm{H} 4), 4.61(1 \mathrm{H}, \mathrm{dd}, J 5.3,7.3 \mathrm{~Hz}, \mathrm{H} 3), 4.92(1 \mathrm{H}, \mathrm{s}, \mathrm{H} 1) ; \delta_{\mathrm{C}}$ $(100.61 \mathrm{MHz}, \mathrm{CDCl})$ 13.80, $14.20\left(\mathrm{CH}_{3}\right), 19.28\left(\mathrm{CH}_{2} \mathrm{CH}_{3}\right), 29.87$, $30.50\left(\mathrm{CH}_{2}\right), 65.58\left(\mathrm{C}_{6} \mathrm{OO}-\underline{\mathrm{CH}_{2}}\right), 67.48\left(\mathrm{C}_{1}-\mathrm{O}-\underline{\mathrm{C}} \mathrm{H}_{2}\right), 69.77$ (C5), 70.93 (C3), 74.56 (C2), 79.58 (C4), 106.21 (C1), 172.78 (ㄷO (C6)).

30: $\delta_{\mathrm{H}}\left(400.13 \mathrm{MHz}, \mathrm{CDCl}_{3}\right) 0.87\left(3 \mathrm{H}, \mathrm{t}, \mathrm{CH}_{3}\right), 0.92\left(3 \mathrm{H}, \mathrm{t}, \mathrm{CH}_{3}\right)$, 1.23-1.25 (2H, m, $\left.\mathrm{CH}_{2} \mathrm{CH}_{3}\right), 1.38-1.42\left(2 \mathrm{H}, \mathrm{m}, \mathrm{CH}_{2}\right), 1.58-1.64$ $\left(2 \mathrm{H}, \mathrm{m}, \mathrm{CH}_{2}\right), 3.50(1 \mathrm{H}, \mathrm{dt}, J 6.6,9.6 \mathrm{~Hz}, \mathrm{C} 1-\mathrm{O}-\mathrm{CH}), 3.74(1 \mathrm{H}, \mathrm{dt}$, J 6.8, $\left.9.8 \mathrm{~Hz}, \mathrm{C} 1-\mathrm{O}-\mathrm{CH}^{\prime}\right), 3.98(1 \mathrm{H}, \mathrm{d}, J 3.9 \mathrm{~Hz}, \mathrm{H} 2), 4.00(1 \mathrm{H}, \mathrm{s}$, $\mathrm{H} 3), 4.17\left(2 \mathrm{H}, \mathrm{t}, J 6.1 \mathrm{~Hz}, \mathrm{C}_{6} \mathrm{OO}-\mathrm{CH}_{2}\right), 4.36(1 \mathrm{H}, \mathrm{d}, J 4.0 \mathrm{~Hz}, \mathrm{H} 4)$, $4.43(1 \mathrm{H}, \mathrm{d}, J 1.5 \mathrm{~Hz}, \mathrm{H} 5), 4.96(1 \mathrm{H}, \mathrm{d}, J 4.1 \mathrm{~Hz}, \mathrm{H} 1) ; \delta_{\mathrm{C}}(100.61$ $\left.\mathrm{MHz}, \mathrm{CDCl}_{3}\right)$ 13.93, $14.20\left(\mathrm{CH}_{3}\right), 19.40\left(\mathrm{CH}_{2} \mathrm{CH}_{3}\right), 29.84,30.50$ $\left(\mathrm{CH}_{2}\right), 64.67(\mathrm{C} 2), 65.79\left(\mathrm{C}_{6} \mathrm{OO}-\mathrm{CH}_{2}\right), 67.47(\mathrm{C} 5), 69.79\left(\mathrm{C}_{1}-\mathrm{O}-\right.$ $\mathrm{CH}_{2}$ ), 70.41 (C4), 71.92 (C3), 100.27 (C1), 169.46 (ㄷOO (C6)).

3ß: $\delta_{\mathrm{H}}\left(400.13 \mathrm{MHz}, \mathrm{CDCl}_{3}\right) 0.88\left(3 \mathrm{H}, \mathrm{t}, \mathrm{CH}_{3}\right), 0.93\left(3 \mathrm{H}, \mathrm{t}, \mathrm{CH}_{3}\right)$, 1.23-1.25 (2H, m, $\left.\mathrm{CH}_{2} \mathrm{CH}_{3}\right), 1.37-1.43\left(2 \mathrm{H}, \mathrm{m}, \mathrm{CH}_{2}\right), 1.59-1.66$ $\left(2 \mathrm{H}, \mathrm{m}, \mathrm{CH}_{2}\right), 3.58(1 \mathrm{H}, \mathrm{dt}, \mathrm{J}$ 6.7, $9.5 \mathrm{~Hz}, \mathrm{C} 1-\mathrm{O}-\mathrm{C} \underline{\mathrm{H}}), 3.73(1 \mathrm{H}, \mathrm{dd}$, J 2.9, $\left.8.1 \mathrm{~Hz}, \mathrm{H} 2), 3.84\left(1 \mathrm{H}, \mathrm{dt}, J 6.8,9.6 \mathrm{~Hz}, \mathrm{C} 1-\mathrm{O}-\mathrm{C}^{\prime}\right)^{\prime}\right), 4.17$ $(1 \mathrm{H}, \mathrm{d}, J 3.4 \mathrm{~Hz}, \mathrm{H} 3), 4.17\left(2 \mathrm{H}, \mathrm{t}, J 5.9 \mathrm{~Hz}, \mathrm{C}_{6} \mathrm{OO}-\mathrm{C}_{2}\right), 4.22(1 \mathrm{H}$, s, H4), $4.39(1 \mathrm{H}, \mathrm{d}, J 1.3 \mathrm{~Hz}, \mathrm{H} 5), 4.64(1 \mathrm{H}, \mathrm{d}, J 7.9 \mathrm{~Hz}, \mathrm{H} 1) ; \delta_{\mathrm{C}}$ (100.61 MHz, CDCl 3$) 13.93,14.20\left(\mathrm{CH}_{3}\right), 19.18\left(\mathrm{CH}_{2} \mathrm{CH}_{3}\right), 29.87$, $30.50\left(\mathrm{CH}_{2}\right), 65.89\left(\mathrm{C}_{6} \mathrm{OO}-\mathrm{CH}_{2}\right), 68.29(\mathrm{C} 2), 69.88(\mathrm{C} 4), 69.95$ $\left(\mathrm{C}_{1}-\mathrm{O}-\underline{\mathrm{CH}}_{2}\right), 71.23$ (C3), 74.25 (C5), 100.90 (C1), 169.88 (ㅁO (C6)).

Direct process to synthesize alkyl-L-guluronamides from Lpolyguluronate

Step 1 - Hydrolysis, Fischer glycosylation and esterification reactions. Sodium L-polyguluronate $(7500 \mathrm{~g} / \mathrm{mol}, \mathrm{DP}=44)(1 \mathrm{~g}$, $5.71 \mathrm{mmol}, 1$ equiv.) was mixed with $2 \mathrm{~mL}$ of deionized water and $778 \mu \mathrm{L}$ of methane sulfonic acid ( $12 \mathrm{mmol}, 2.1$ equiv.). 80 $\mathrm{mL}$ of butanol (150 equiv.) were then added to the solution of polyguluronate. In refluxing butanol $\left(130-135^{\circ} \mathrm{C}\right)$, the mixture was vigorously stirred for 12 hours. Water present in the medium and formed during the glycosylation and esterification reactions was progressively eliminated in a Dean Stark material filled with butanol by azeotropic evaporation $\left(\mathrm{H}_{2} \mathrm{O} / \mathrm{BuOH}\right)$. After 12 hours, the reaction mixture was allowed to cool down to room temperature, then a thin layer chromatography $\left(\mathrm{CH}_{2} \mathrm{Cl}_{2} / \mathrm{CH}_{3} \mathrm{OH} 95 / 5 \mathrm{v} / \mathrm{v}\right)$ and ${ }^{1} \mathrm{H}$ and ${ }^{13} \mathrm{C} \mathrm{NMR}$ experiments $\left(\mathrm{CDCl}_{3}\right)$ were carried out for the medium to ensure that the expected products were synthesized.

Step 2 - Aminolysis reaction. The medium temperature was adjusted to $60^{\circ} \mathrm{C}$ before adding 3 molar equiv. (17.14 mmol) of fatty amines $\mathrm{C}_{n} \mathrm{H}_{2 n+1} \mathrm{NH}_{2}(\mathrm{n}=12,3.18 \mathrm{~g} ; \mathrm{n}=18,4.62 \mathrm{~g}$ ) needed to raise the $\mathrm{pH}$ to 8.5 . After $30 \mathrm{~min}$. of stirring at $65^{\circ} \mathrm{C}$ and under vacuum (150 mbar), BuOH was evaporated by reducing the medium pressure, progressively, to 6 mbar. The reaction medium was stirred at $65^{\circ} \mathrm{C}$ for 1 hour and a half under vacuum ( 6 mbar) until $\mathrm{BuOH}$ gas evolution stopped.

The obtained residue was taken up in diethyl ether then filtered on Büchner and rinsed several times with diethyl ether in order to remove salts and unreacted sugars. The organic layer (containing $N$-( $n$-alkyl)- $n$-butyl-L-guluronamides) was concentrated under vacuum to remove diethyl ether and a crude brown oil was obtained.

- For $\mathrm{n}=12$, the crude oil was purified by silica gel chromatography (80 g, eluent $\mathrm{CH}_{2} \mathrm{Cl}_{2} / \mathrm{CH}_{3} \mathrm{OH} 95 / 5 \mathrm{v} / \mathrm{v}$ ) to provide $0.95 \mathrm{~g}(2.27 \mathrm{mmol}, 40 \%)$ of a mixture of 4 isomers named GulC $_{4} \mathbf{N}_{12}$ as a brown oil. This mixture is composed of: $N$-( $n$-dodecyl)- $n$-butyl $\alpha$-L-gulofuranosiduronamide $\underline{4 \alpha}(21 \%)$, $N$-(n-dodecyl)- $n$-butyl $\beta$-L-gulofuranosiduronamide $4 \beta$ (37\%), $N$-(n-dodecyl)- $n$-butyl $\alpha$-L-gulopyranosiduronamide $\underline{6 \alpha}(28 \%)$, $N$-(n-dodecyl)- $n$-butyl $\beta$-L-gulopyranosiduronamide $\underline{6} \boldsymbol{\beta}$ (14\%) with an $\alpha / \beta$ ratio $=49 / 51$ and a pyranose $/$ furanose ratio $=$ 42/58. Rf 0.45, 0.41, 0.37 and $0.34\left(\mathrm{CH}_{2} \mathrm{Cl}_{2} / \mathrm{MeOH}: 95 / 5 \mathrm{v} / \mathrm{v}\right)$. $\mathrm{M}_{\mathrm{w}}=417.59$ g.mol ${ }^{-1}$ requires $\mathrm{C}_{22} \mathrm{H}_{43} \mathrm{NO}_{6}\left(\mathrm{~m} / z(\mathrm{ESI}+)[\mathrm{M}+\mathrm{Na}]^{+}=\right.$ 440.2).

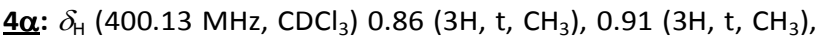
$1.24\left(18 \mathrm{H}, \mathrm{s}, \mathrm{CH}_{2}\right), 1.33-1.42\left(2 \mathrm{H}, \mathrm{m}, \mathrm{CH}_{2}\right), 1.46-1.63(4 \mathrm{H}, \mathrm{m}$, $\left.\mathrm{CH}_{2}\right), 3.22-3.32\left(2 \mathrm{H}, \mathrm{m}, \mathrm{NH}-\mathrm{CH}_{2}\right), 3.49(1 \mathrm{H}, \mathrm{dt}, J 6.7,9.7 \mathrm{~Hz}, \mathrm{C} 1-$ $\mathrm{O}-\mathrm{C} \underline{\mathrm{H}}), 3.78\left(1 \mathrm{H}, \mathrm{dt}, J 6.8,9.7 \mathrm{~Hz}, \mathrm{C} 1-\mathrm{O}-\mathrm{CH}^{\prime}\right), 4.11(1 \mathrm{H}, \mathrm{d}, J 4.9$ $\mathrm{Hz}, \mathrm{H} 2), 4.29(1 \mathrm{H}, \mathrm{d}, J 2.5 \mathrm{~Hz}, \mathrm{H} 4), 4.30(1 \mathrm{H}, \mathrm{s}, \mathrm{H} 3), 4.41(1 \mathrm{H}, \mathrm{d}, J$ $4.0 \mathrm{~Hz}, \mathrm{H} 5), 4.94(1 \mathrm{H}, \mathrm{d}, J 4.8 \mathrm{~Hz}, \mathrm{H} 1), 6.96(1 \mathrm{H}, \mathrm{t}, J 5.9 \mathrm{~Hz}, \mathrm{NH})$; $\delta_{\mathrm{C}}\left(100.61 \mathrm{MHz}, \mathrm{CDCl}_{3}\right)$ 13.96, $14.22\left(\mathrm{CH}_{3}\right), 19.37\left(\mathrm{CH}_{2} \mathrm{CH}_{3}\right)$, 22.79, 26.96-32.02 $\left(\mathrm{CH}_{2}\right), 39.35\left(\mathrm{NH}-\mathrm{CH}_{2}\right), 69.18\left(\mathrm{C}_{1}-\mathrm{O}-\mathrm{CH}_{2}\right)$, 70.54 (C3), 71.56 (C5), 72.69 (C2), 81.52 (C4), 101.51 (C1), $171.36(\mathrm{C} 6)$.

4ㅅ: $\delta_{\mathrm{H}}\left(400.13 \mathrm{MHz}, \mathrm{CDCl}_{3}\right) 0.86\left(3 \mathrm{H}, \mathrm{t}, \mathrm{CH}_{3}\right), 0.89\left(3 \mathrm{H}, \mathrm{m}, \mathrm{CH}_{3}\right)$, $1.24\left(18 \mathrm{H}, \mathrm{s}, \mathrm{CH}_{2}\right), 1.29-1.36\left(2 \mathrm{H}, \mathrm{m}, \mathrm{CH}_{2}\right), 1.45-1.53(4 \mathrm{H}, \mathrm{m}$, $\left.\mathrm{CH}_{2}\right), 3.18-3.29\left(2 \mathrm{H}, \mathrm{m}, \mathrm{NH}-\mathrm{C}_{2} 2\right), 3.34(1 \mathrm{H}, \mathrm{dt}, J 6.5,9.5 \mathrm{~Hz}, \mathrm{C} 1-$ $\mathrm{O}-\mathrm{C} \underline{\mathrm{H}}), 3.61\left(1 \mathrm{H}, \mathrm{dt}, J 6.7,9.6 \mathrm{~Hz}, \mathrm{C} 1-\mathrm{O}-\mathrm{CH}^{\prime}\right), 3.97(1 \mathrm{H}, \mathrm{d}, J 4.9$ $\mathrm{Hz}, \mathrm{H} 2), 4.26(1 \mathrm{H}, \mathrm{d}, J 3.2 \mathrm{~Hz}, \mathrm{H} 5), 4.32(1 \mathrm{H}, \mathrm{dd}, J 3.1,7.2 \mathrm{~Hz}$, $\mathrm{H} 4), 4.62(1 \mathrm{H}, \mathrm{dd}, J 5.0,7.2 \mathrm{~Hz}, \mathrm{H} 3), 4.90(1 \mathrm{H}, \mathrm{s}, \mathrm{H} 1), 7.10(1 \mathrm{H}$, $\mathrm{t}, J 5.9 \mathrm{~Hz}, \mathrm{NH}) ; \delta_{\mathrm{C}}\left(100.61 \mathrm{MHz}, \mathrm{CDCl}_{3}\right) 13.91,14.21\left(\mathrm{CH}_{3}\right)$, $19.31\left(\mathrm{CH}_{2} \mathrm{CH}_{3}\right), 22.79,26.95-32.02\left(\mathrm{CH}_{2}\right), 39.51\left(\mathrm{NH}-\underline{C H}_{2}\right)$, $67.74\left(\mathrm{C}_{1}-\mathrm{O}-\mathrm{CH}_{2}\right), 69.77$ (C5), 70.98 (C3), 74.55 (C2), 79.58 (C4), 106.36 (C1), 172.98 (C6).

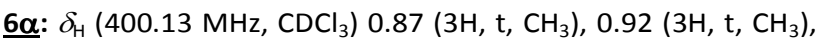
$1.25\left(18 \mathrm{H}, \mathrm{s}, \mathrm{CH}_{2}\right), 1.30-1.42\left(2 \mathrm{H}, \mathrm{m}, \mathrm{CH}_{2}\right), 1.43-1.58(4 \mathrm{H}, \mathrm{m}$, $\left.\mathrm{CH}_{2}\right), 3.19-3.33\left(2 \mathrm{H}, \mathrm{m}, \mathrm{NH}-\mathrm{C}_{2}\right), 3.50(1 \mathrm{H}, \mathrm{dt}, J 6.6,9.7 \mathrm{~Hz}, \mathrm{C} 1-$ $\mathrm{O}-\mathrm{C} \underline{\mathrm{H}}), 3.74\left(1 \mathrm{H}, \mathrm{dt}, J 6.8,9.8 \mathrm{~Hz}, \mathrm{C} 1-\mathrm{O}-\mathrm{CH}^{\prime}\right), 3.98(1 \mathrm{H}, \mathrm{d}, J 3.9$ $\mathrm{Hz}, \mathrm{H} 2), 4.00(1 \mathrm{H}, \mathrm{s}, \mathrm{H} 3), 4.34(1 \mathrm{H}, \mathrm{d}, J 4.4 \mathrm{~Hz}, \mathrm{H} 4), 4.43(1 \mathrm{H}, \mathrm{d}, J$ $1.5 \mathrm{~Hz}, \mathrm{H} 5), 4.96(1 \mathrm{H}, \mathrm{d}, J 4.1 \mathrm{~Hz}, \mathrm{H} 1), 6.70(1 \mathrm{H}, \mathrm{t}, J 5.8 \mathrm{~Hz}, \mathrm{NH})$; $\delta_{\mathrm{C}}\left(100.61 \mathrm{MHz}, \mathrm{CDCl}_{3}\right)$ 13.92, $14.24\left(\mathrm{CH}_{3}\right), 19.43\left(\mathrm{C}_{2} \mathrm{CH}_{3}\right)$, 22.81, 27.05-32.04 $\left(\mathrm{CH}_{2}\right), 39.43\left(\mathrm{NH}-\mathrm{CH}_{2}\right), 64.77(\mathrm{C} 2), 67.67$ (C5), $69.69\left(\mathrm{C}_{1}-\mathrm{O}-\underline{\mathrm{C}} \mathrm{H}_{2}\right), 70.51$ (C4), 71.92 (C3), 100.20 (C1), 169.77 (C6).

6ß: $\delta_{\mathrm{H}}\left(400.13 \mathrm{MHz}, \mathrm{CDCl}_{3}\right) 0.88\left(3 \mathrm{H}, \mathrm{t}, \mathrm{CH}_{3}\right), 0.93\left(3 \mathrm{H}, \mathrm{t}, \mathrm{CH}_{3}\right)$, $1.25\left(18 \mathrm{H}, \mathrm{s}, \mathrm{CH}_{2}\right), 1.27-1.33\left(2 \mathrm{H}, \mathrm{m}, \mathrm{CH}_{2}\right), 1.35-1.66(4 \mathrm{H}, \mathrm{m}$,

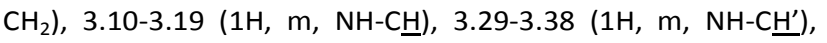
$3.58(1 \mathrm{H}, \mathrm{dt}, J 6.7,9.7 \mathrm{~Hz}, \mathrm{C} 1-\mathrm{O}-\mathrm{C} \underline{\mathrm{H}}), 3.73(1 \mathrm{H}, \mathrm{dd}, J 2.9,8.1 \mathrm{~Hz}$, $\mathrm{H} 2), 3.87\left(1 \mathrm{H}, \mathrm{dt}, J 6.8,9.6 \mathrm{~Hz}, \mathrm{C} 1-\mathrm{O}-\mathrm{CH}^{\prime}\right), 4.16(1 \mathrm{H}, \mathrm{d}, J 3.4 \mathrm{~Hz}$, 
H3), $4.20(1 \mathrm{H}, \mathrm{s}, \mathrm{H} 4), 4.39(1 \mathrm{H}, \mathrm{d}, J 1.2 \mathrm{~Hz}, \mathrm{H} 5), 4.64(1 \mathrm{H}, \mathrm{d}, J 8.1$ $\mathrm{Hz}, \mathrm{H} 1), 6.80(1 \mathrm{H}, \mathrm{t}, J 5.9 \mathrm{~Hz}, \mathrm{NH}) ; \delta_{\mathrm{C}}\left(100.61 \mathrm{MHz}, \mathrm{CDCl}_{3}\right)$ 13.96, $14.22\left(\mathrm{CH}_{3}\right), 19.28\left(\mathrm{CH}_{2} \mathrm{CH}_{3}\right), 22.80,27.08-32.03\left(\mathrm{CH}_{2}\right)$, $39.42\left(\mathrm{NH}-\mathrm{CH}_{2}\right), 68.38(\mathrm{C} 2), 69.88(\mathrm{C} 4), 69.99\left(\mathrm{C}_{1}-\mathrm{O}-\underline{\mathrm{CH}}_{2}\right), 71.20$ (C3), 74.14 (C5), 100.98 (C1), 169.97 (C6).

- For $\mathrm{n}=18$, the crude oil was purified by silica gel chromatography ( $80 \mathrm{~g}$, eluent $\mathrm{CH}_{2} \mathrm{Cl}_{2} / \mathrm{CH}_{3} \mathrm{OH} 95 / 5 \mathrm{v} / \mathrm{v}$ ) to provide $1.08 \mathrm{~g}(2.16 \mathrm{mmol}, 38 \%)$ of a mixture of 4 isomers named GulC $\mathbf{C}_{\mathbf{1 8}}$ as a brown oil. This mixture is composed of: $N$-(n-octadecyl)-n-butyl $\alpha$-L-gulofuranosiduronamide $\mathbf{5 \alpha}(23 \%)$, $N$-(n-octadecyl)-n-butyl $\beta$-L-gulofuranosiduronamide $\mathbf{5} \boldsymbol{\beta}$ (36\%), $N$-(n-octadecyl)-n-butyl $\alpha$-L-gulopyranosiduronamide $\underline{7 \alpha}$ (25\%), $N$-(n-octadecyl)-n-butyl $\beta$-L-gulopyranosiduronamide $\underline{7} \beta$ (16\%) with an $\alpha / \beta$ ratio $=48 / 52$ and a pyranose $/$ furanose ratio $=$ 41/59. $R f$ 0.47, 0.44, 0.39 and $0.35\left(\mathrm{CH}_{2} \mathrm{Cl}_{2} / \mathrm{MeOH}: 95 / 5 \mathrm{v} / \mathrm{v}\right)$. $\mathrm{M}_{\mathrm{w}}=501.75$ requires $\mathrm{C}_{28} \mathrm{H}_{55} \mathrm{NO}_{6}\left(\mathrm{~m} / z(\mathrm{ESI}+)[\mathrm{M}+\mathrm{Na}]^{+}=524.35\right)$. 5 $\mathbf{\alpha}: \delta_{\mathrm{H}}\left(400.13 \mathrm{MHz}, \mathrm{CDCl}_{3}\right) 0.87\left(3 \mathrm{H}, \mathrm{t}, \mathrm{CH}_{3}\right), 0.93\left(3 \mathrm{H}, \mathrm{t}, \mathrm{CH}_{3}\right)$, $1.25\left(30 \mathrm{H}, \mathrm{s}, \mathrm{CH}_{2}\right), 1.31-1.42\left(2 \mathrm{H}, \mathrm{m}, \mathrm{CH}_{2}\right), 1.49-1.62(4 \mathrm{H}, \mathrm{m}$, $\left.\mathrm{CH}_{2}\right), 3.25-3.34\left(2 \mathrm{H}, \mathrm{m}, \mathrm{NH}-\mathrm{CH}_{2}\right), 3.52(1 \mathrm{H}, \mathrm{dt}, J 6.6,9.7 \mathrm{~Hz}, \mathrm{C} 1-$ $\mathrm{O}-\mathrm{C} \underline{\mathrm{H}}), 3.80\left(1 \mathrm{H}, \mathrm{dt}, J 6.7,9.7 \mathrm{~Hz}, \mathrm{C} 1-\mathrm{O}-\mathrm{C}^{\prime}{ }^{\prime}\right), 4.14(1 \mathrm{H}, \mathrm{d}, J 5.2$ $\mathrm{Hz}, \mathrm{H} 2), 4.28(1 \mathrm{H}, \mathrm{d}, J 5.1 \mathrm{~Hz}, \mathrm{H} 4), 4.30(1 \mathrm{H}, \mathrm{d}, J 5.3 \mathrm{~Hz}, \mathrm{H} 3)$, $4.44(1 \mathrm{H}, \mathrm{d}, J 5.0 \mathrm{~Hz}, \mathrm{H} 5), 4.96(1 \mathrm{H}, \mathrm{d}, J 4.8 \mathrm{~Hz}, \mathrm{H} 1), 6.95(1 \mathrm{H}, \mathrm{t}$, J $5.7 \mathrm{~Hz}, \mathrm{NH})$; $\delta_{\mathrm{C}}\left(100.61 \mathrm{MHz}, \mathrm{CDCl}_{3}\right) 13.96,14.26\left(\mathrm{CH}_{3}\right), 19.41$ $\left(\underline{\mathrm{CH}_{2}} \mathrm{CH}_{3}\right), 22.83,26.99-32.07\left(\mathrm{CH}_{2}\right), 39.37\left(\mathrm{NH}-\mathrm{CH}_{2}\right), 69.31\left(\mathrm{C}_{1-}\right.$ $\mathrm{O}-\mathrm{CH}_{2}$ ), 70.40 (C3), 71.59 (C5), 72.75 (C2), 81.74 (C4), 101.69 (C1), 171.18 (C6).

5 1 : $\delta_{\mathrm{H}}\left(400.13 \mathrm{MHz}, \mathrm{CDCl}_{3}\right) 0.87\left(3 \mathrm{H}, \mathrm{t}, \mathrm{CH}_{3}\right), 0.92\left(3 \mathrm{H}, \mathrm{m},-\mathrm{CH}_{3}\right)$, $1.24\left(30 \mathrm{H}, \mathrm{s}, \mathrm{CH}_{2}\right), 1.30-1.41\left(2 \mathrm{H}, \mathrm{m}, \mathrm{CH}_{2}\right), 1.46-1.59(4 \mathrm{H}, \mathrm{m}$, $\left.\mathrm{CH}_{2}\right), 3.19-3.30\left(2 \mathrm{H}, \mathrm{m}, \mathrm{NH}-\mathrm{CH}_{2}\right), 3.37(1 \mathrm{H}, \mathrm{dt}, J 6.5,9.6 \mathrm{~Hz}, \mathrm{C} 1-$ $\mathrm{O}-\mathrm{CH}), 3.63\left(1 \mathrm{H}, \mathrm{dt}, J 6.8,9.6 \mathrm{~Hz}, \mathrm{C} 1-\mathrm{O}-\mathrm{C}_{\underline{H^{\prime}}}\right), 4.03(1 \mathrm{H}, \mathrm{d}, J 5.1$ $\mathrm{Hz}, \mathrm{H} 2), 4.28(1 \mathrm{H}, \mathrm{dd}, J 4.5,6.8 \mathrm{~Hz}, \mathrm{H} 4), 4.33(1 \mathrm{H}, \mathrm{d}, J 4.7 \mathrm{~Hz}$, H5), $4.59(1 \mathrm{H}, \mathrm{dd}, J 5.0,6.7 \mathrm{~Hz}, \mathrm{H3}), 4.93(1 \mathrm{H}, \mathrm{s}, \mathrm{H} 1), 7.01(1 \mathrm{H}$, $\mathrm{t}, J 5.9 \mathrm{~Hz}, \mathrm{NH}) ; \delta_{\mathrm{C}}\left(100.61 \mathrm{MHz}, \mathrm{CDCl}_{3}\right) 13.95,14.25\left(\mathrm{CH}_{3}\right)$, $19.35\left(\mathrm{CH}_{2} \mathrm{CH}_{3}\right), 22.82,26.98-32.06\left(\mathrm{CH}_{2}\right), 39.47\left(\mathrm{NH}-\mathrm{CH}_{2}\right)$, $67.85\left(\mathrm{C}_{1}-\mathrm{O}-\mathrm{CH}_{2}\right), 70.18(\mathrm{C} 5), 70.95$ (C3), 74.92 (C2), 79.93 (C4), $106.49(\mathrm{C} 1), 172.44(\mathrm{C} 6)$

7 $\alpha$ : $\delta_{\mathrm{H}}\left(400.13 \mathrm{MHz}, \mathrm{CDCl}_{3}\right) 0.86\left(3 \mathrm{H}, \mathrm{t}, \mathrm{CH}_{3}\right), 0.94\left(3 \mathrm{H}, \mathrm{t}, \mathrm{CH}_{3}\right)$, $1.25\left(30 \mathrm{H}, \mathrm{s}, \mathrm{CH}_{2}\right), 1.34-1.44\left(2 \mathrm{H}, \mathrm{m}, \mathrm{CH}_{2}\right), 1.47-1.64(4 \mathrm{H}, \mathrm{m}$, $\left.\mathrm{CH}_{2}\right), 3.16-3.32\left(2 \mathrm{H}, \mathrm{m}, \mathrm{NH}-\mathrm{CH}_{2}\right), 3.50(1 \mathrm{H}, \mathrm{dt}, J 6.6,9.8 \mathrm{~Hz}, \mathrm{C} 1-$ $\mathrm{O}-\mathrm{C} \underline{\mathrm{H}}), 3.75\left(1 \mathrm{H}, \mathrm{dt}, J 6.8,9.9 \mathrm{~Hz}, \mathrm{C} 1-\mathrm{O}-\mathrm{C}_{\mathrm{H}^{\prime}}\right), 3.97(1 \mathrm{H}, \mathrm{dd}, J 3.7$, $8.0 \mathrm{~Hz}, \mathrm{H} 2), 4.00(1 \mathrm{H}, \mathrm{s}, \mathrm{H} 3), 4.37(1 \mathrm{H}, \mathrm{d}, J 5.5 \mathrm{~Hz}, \mathrm{H} 4), 4.44(1 \mathrm{H}$, d, J $1.7 \mathrm{~Hz}, \mathrm{H} 5), 4.97(1 \mathrm{H}, \mathrm{d}, J 4.0 \mathrm{~Hz}, \mathrm{H} 1), 6.69(1 \mathrm{H}, \mathrm{t}, J 6.0 \mathrm{~Hz}$, $\mathrm{NH}) ; \quad \delta_{\mathrm{C}}\left(100.61 \mathrm{MHz}, \mathrm{CDCl}_{3}\right) 13.93,14.26\left(\mathrm{CH}_{3}\right), 19.44$ $\left(\mathrm{CH}_{2} \mathrm{CH}_{3}\right), 22.83,27.06-32.07\left(\mathrm{CH}_{2}\right), 39.45\left(\mathrm{NH}-\mathrm{CH}_{2}\right), 64.77$ (C2), 67.66 (C5), $69.71\left(\mathrm{C}_{1}-\mathrm{O}-\underline{\mathrm{C}}_{2}\right), 70.55$ (C4), 71.93 (C3), 100.23 (C1), $169.70(\mathrm{C} 6)$.

7ß: $\delta_{\mathrm{H}}\left(400.13 \mathrm{MHz}, \mathrm{CDCl}_{3}\right) 0.87\left(3 \mathrm{H}, \mathrm{t}, \mathrm{CH}_{3}\right), 0.93\left(3 \mathrm{H}, \mathrm{t}, \mathrm{CH}_{3}\right)$, $1.25\left(30 \mathrm{H}, \mathrm{s}, \mathrm{CH}_{2}\right), 1.29-1.34\left(2 \mathrm{H}, \mathrm{m}, \mathrm{CH}_{2}\right), 1.37-1.65(4 \mathrm{H}, \mathrm{m}$, $\left.\mathrm{CH}_{2}\right), 3.12-3.22(1 \mathrm{H}, \mathrm{m}, \mathrm{NH}-\mathrm{C} \underline{\mathrm{H}}), 3.27-3.38\left(1 \mathrm{H}, \mathrm{m}, \mathrm{NH}-\mathrm{CH}^{\prime}\right)$, $3.58(1 \mathrm{H}, \mathrm{dt}, J 6.7,9.7 \mathrm{~Hz}, \mathrm{C} 1-\mathrm{O}-\mathrm{C} \underline{\mathrm{H}}), 3.74(1 \mathrm{H}, \mathrm{dd}, J 3.2,8.1 \mathrm{~Hz}$, $\mathrm{H} 2), 3.88\left(1 \mathrm{H}, \mathrm{dt}, J 6.7,9.7 \mathrm{~Hz}, \mathrm{C} 1-\mathrm{O}-\mathrm{CH}^{\prime}\right), 4.17(1 \mathrm{H}, \mathrm{d}, J 3.4 \mathrm{~Hz}$, $\mathrm{H} 3), 4.23(1 \mathrm{H}, \mathrm{s}, \mathrm{H} 4), 4.39(1 \mathrm{H}, \mathrm{d}, J 1.4 \mathrm{~Hz}, \mathrm{H} 5), 4.65(1 \mathrm{H}, \mathrm{d}, J 8.1$ $\mathrm{Hz}, \mathrm{H} 1), 6.75(1 \mathrm{H}, \mathrm{t}, J 5.8 \mathrm{~Hz}, \mathrm{NH}) ; \delta_{\mathrm{C}}\left(100.61 \mathrm{MHz}, \mathrm{CDCl}_{3}\right)$ 13.99, $14.27\left(\mathrm{CH}_{3}\right), 19.32\left(\mathrm{CH}_{2} \mathrm{CH}_{3}\right), 22.84,27.10-32.07\left(\mathrm{CH}_{2}\right)$, $39.44\left(\mathrm{NH}-\mathrm{CH}_{2}\right), 68.49(\mathrm{C} 2), 69.82(\mathrm{C} 4), 69.99\left(\mathrm{C}_{1}-\mathrm{O}-\underline{\mathrm{CH}}_{2}\right), 71.17$ (C3), 74.24 (C5), 100.98 (C1), 169.85 (C6).
Direct process to synthesize alkyl-L-guluronamide and alkyl-Dmannuronamide monosaccharides from alginate (without previous neutralization of the medium before aminolysis reaction)

Step 1 - Butanolysis and Fischer glycosylation reaction. Sodium alginate $(110200 \mathrm{~g} / \mathrm{mol}, \mathrm{DP}=630)$ which $\mathrm{M} / \mathrm{G}$ ratio is about 0.78 ( $1 \mathrm{~g}, 5.71 \mathrm{mmol}, 1$ equiv.) was mixed with $3 \mathrm{~mL}$ of deionized water and $927 \mu \mathrm{L}$ of methane sulfonic acid (14.27 mmol, 2.5 equiv.). $80 \mathrm{~mL}$ of $\mathrm{BuOH}$ (150 equiv.) were then added to the solution of sodium alginate. In refluxing butanol $\left(130-135^{\circ} \mathrm{C}\right)$, the mixture was vigorously stirred for $24 \mathrm{~h}$. Water present in the medium and formed during the glycosylation and esterification reactions was progressively eliminated in a Dean Stark material filled with butanol by azeotropic evaporation $\left(\mathrm{H}_{2} \mathrm{O} / \mathrm{BuOH}\right)$. After $24 \mathrm{~h}$, the reaction mixture was allowed to cool down to room temperature, then a thin layer chromatography $\left(\mathrm{CH}_{2} \mathrm{Cl}_{2} / \mathrm{CH}_{3} \mathrm{OH} 95 / 5 \mathrm{v} / \mathrm{v}\right)$ and ${ }^{1} \mathrm{H}$ and ${ }^{13} \mathrm{C} N M R$ experiments $\left(\mathrm{CDCl}_{3}\right)$ were carried out for the medium to ensure that the expected products were synthesized.

Step 2 - Aminolysis reaction. The medium temperature was adjusted to $60^{\circ} \mathrm{C}$ before adding 3 molar equiv. (17.14 mmol) of fatty amines $\mathrm{C}_{n} \mathrm{H}_{2 n+1} \mathrm{NH}_{2}(\mathrm{n}=12,3.18 \mathrm{~g} ; \mathrm{n}=17,4.62 \mathrm{~g}$ ) needed to raise the $\mathrm{pH}$ to 8.5 . After $30 \mathrm{~min}$. of stirring at $65^{\circ} \mathrm{C}$ and under vacuum (150 mbar), $\mathrm{BuOH}$ was evaporated by reducing the medium pressure, progressively, to 6 mbar. The reaction medium was stirred at $65^{\circ} \mathrm{C}$ for 1 hour and a half under vacuum (6 mbar) until $\mathrm{BuOH}$ gas evolution stopped.

The obtained residue was taken up in diethyl ether then filtered on Büchner and rinsed several times with diethyl ether in order to remove salts and unreacted sugar. The organic layer (containing $N$-( $n$-alkyl)- $n$-butyl-L-guluronamides and $N$ - $(n$ alkyl)-n-butyl-D-mannuronamides) was concentrated under vacuum to remove diethyl ether and a crude brown oil was obtained.

- For $\mathrm{n}=12$, the crude oil was purified by silica gel chromatography (80 g, eluent $\mathrm{CH}_{2} \mathrm{Cl}_{2} / \mathrm{CH}_{3} \mathrm{OH} 95 / 5 \mathrm{v} / \mathrm{v}$ ) to provide $0.95 \mathrm{~g}(2.18 \mathrm{mmol}, 40 \%)$ of a mixture of 6 isomers named $\mathbf{A l g} \mathbf{C}_{\mathbf{4}} \mathbf{N}_{\mathbf{1 2}}$ as a brown oil. This mixture is composed of: $N$-(n-dodecyl)- $n$-butyl $\alpha$-L-gulofuranosiduronamide $\underline{4 \alpha}$ (14\%), $N$-(n-dodecyl)- $n$-butyl $\beta$-L-gulofuranosiduronamide $\overline{4 \beta}$ (26\%), $N$-(n-dodecyl)- $n$-butyl $\alpha$-L-gulopyranosiduronamide $\underline{6 \alpha}(16 \%)$, $N$-( $n$-dodecyl)- $n$-butyl $\beta$-L-gulopyranosiduronamide $\mathbf{6 \beta}$ (12\%), $N$-(n-dodecyl)- $n$-butyl $\alpha$-D-mannofuranosiduronamide $\quad \underline{\mathbf{8 \alpha}}$ (18\%), $N$-(n-dodecyl)- $n$-butyl $\alpha$-D-mannopyranosiduronamide $10 \alpha(14 \%)$ with an $\alpha / \beta$ ratio $=38 / 62$, a guluronamide pyranose/furanose ratio $=0.72$, a mannuronamide pyranose/furanose ratio $=0.81$. Man/Gul ratio $=0.47 . R f 0.45$, $0.41,0.37$ and $0.34\left(\mathrm{CH}_{2} \mathrm{Cl}_{2} / \mathrm{MeOH}: 95 / 5 \mathrm{v} / \mathrm{v}\right) . \mathrm{M}_{\mathrm{w}}=417.59$ requires $\mathrm{C}_{22} \mathrm{H}_{43} \mathrm{NO}_{6}\left(\mathrm{~m} / z(\mathrm{ESI}+)[\mathrm{M}+\mathrm{Na}]^{+}=440.2\right)$.

4a $: \delta_{\mathrm{H}}\left(400.13 \mathrm{MHz}, \mathrm{CDCl}_{3}\right) 0.85\left(3 \mathrm{H}, \mathrm{t}, \mathrm{CH}_{3}\right), 0.90\left(3 \mathrm{H}, \mathrm{t}, \mathrm{CH}_{3}\right)$, $1.24\left(18 \mathrm{H}, \mathrm{s}, \mathrm{CH}_{2}\right), 1.28-1.36\left(2 \mathrm{H}, \mathrm{m}, \mathrm{CH}_{2}\right), 1.47-1.61(4 \mathrm{H}, \mathrm{m}$, $\left.\mathrm{CH}_{2}\right), 3.15-3.32\left(2 \mathrm{H}, \mathrm{m}, \mathrm{NH}-\underline{\mathrm{C}}_{2}\right), 3.50(1 \mathrm{H}, \mathrm{dt}, J 6.6,9.6 \mathrm{~Hz}, \mathrm{C} 1-$ O-Cㅂ) , $3.79\left(1 \mathrm{H}, \mathrm{dt}, J 6.6,9.5 \mathrm{~Hz}, \mathrm{C} 1-\mathrm{O}-\mathrm{CH}^{\prime}\right), 4.10(1 \mathrm{H}, \mathrm{d}, J 4.7$ $\mathrm{Hz}, \mathrm{H} 2), 4.29(1 \mathrm{H}, \mathrm{s}, \mathrm{H} 4), 4.31(1 \mathrm{H}, \mathrm{s}, \mathrm{H} 3), 4.42(1 \mathrm{H}, \mathrm{d}, J 3.5 \mathrm{~Hz}$, H5), $4.97(1 \mathrm{H}, \mathrm{d}, J 4.7 \mathrm{~Hz}, \mathrm{H} 1), 6.79(1 \mathrm{H}, \mathrm{t}, J 5.9 \mathrm{~Hz}, \mathrm{NH}) ; \delta_{\mathrm{C}}$ $\left(100.61 \mathrm{MHz}, \mathrm{CDCl}_{3}\right)$ 13.98, $14.26\left(\mathrm{CH}_{3}\right), 19.43\left(\mathrm{CH}_{2} \mathrm{CH}_{3}\right), 22.83$, 
26.99-32.07 $\left(\mathrm{CH}_{2}\right), 39.57\left(\mathrm{NH}-\underline{\mathrm{CH}}_{2}\right), 69.48\left(\mathrm{C}_{1}-\mathrm{O}-\underline{\mathrm{C}} \mathrm{H}_{2}\right), 70.88$ (C3), 71.15 (C5), 72.54 (C2), 80.80 (C4), 101.87 (C1), 171.67 (C6).

4ㅇ: $\delta_{\mathrm{H}}\left(400.13 \mathrm{MHz}, \mathrm{CDCl}_{3}\right) 0.87\left(3 \mathrm{H}, \mathrm{t}, \mathrm{CH}_{3}\right), 0.91\left(3 \mathrm{H}, \mathrm{m}, \mathrm{CH}_{3}\right)$, $1.25\left(18 \mathrm{H}, \mathrm{s}, \mathrm{CH}_{2}\right), 1.29-1.35\left(2 \mathrm{H}, \mathrm{m}, \mathrm{CH}_{2}\right), 1.46-1.59(4 \mathrm{H}, \mathrm{m}$, $\left.\mathrm{CH}_{2}\right), 3.17-3.31\left(2 \mathrm{H}, \mathrm{m}, \mathrm{NH}-\mathrm{C}_{2}\right), 3.37(1 \mathrm{H}, \mathrm{dt}, J 6.5,9.6 \mathrm{~Hz}, \mathrm{C} 1-$ $\mathrm{O}-\mathrm{C} \underline{\mathrm{H}}), 3.63\left(1 \mathrm{H}, \mathrm{dt}, J 6.8,9.6 \mathrm{~Hz}, \mathrm{C} 1-\mathrm{O}-\mathrm{C}^{\mathrm{H}^{\prime}}\right), 4.03(1 \mathrm{H}, \mathrm{d}, J 4.9$ $\mathrm{Hz}, \mathrm{H} 2), 4.27(1 \mathrm{H}, \mathrm{dd}, J 4.6,6.5 \mathrm{~Hz}, \mathrm{H} 4), 4.33(1 \mathrm{H}, \mathrm{d}, J 4.6 \mathrm{~Hz}$, H5), $4.59(1 \mathrm{H}, \mathrm{d}, J 6.0 \mathrm{~Hz}, \mathrm{H} 3), 4.95(1 \mathrm{H}, \mathrm{s}, \mathrm{H} 1), 7.02(1 \mathrm{H}, \mathrm{t}, J 5.9$ $\mathrm{Hz}, \mathrm{NH}) ; \delta_{\mathrm{C}}\left(100.61 \mathrm{MHz}, \mathrm{CDCl}_{3}\right) 13.94,14.24\left(\mathrm{CH}_{3}\right), 19.34$ $\left(\mathrm{CH}_{2} \mathrm{CH}_{3}\right), 22.82,26.97-32.04\left(\mathrm{CH}_{2}\right), 39.48\left(\mathrm{NH}-\mathrm{CH}_{2}\right), 67.85\left(\mathrm{C}_{1^{-}}\right.$ $\mathrm{O}-\mathrm{CH}_{2}$ ), 70.12 (C5), 70.91 (C3), 74.89 (C2), 79.91 (C4), 106.52 (C1), 172.53 (C6).

6a : $\delta_{\mathrm{H}}\left(400.13 \mathrm{MHz}, \mathrm{CDCl}_{3}\right) 0.87\left(3 \mathrm{H}, \mathrm{t}, \mathrm{CH}_{3}\right), 0.92\left(3 \mathrm{H}, \mathrm{t}, \mathrm{CH}_{3}\right)$, $1.25\left(18 \mathrm{H}, \mathrm{s}, \mathrm{CH}_{2}\right), 1.33-1.42\left(2 \mathrm{H}, \mathrm{m}, \mathrm{CH}_{2}\right), 1.48-1.64(4 \mathrm{H}, \mathrm{m}$, $\left.\mathrm{CH}_{2}\right), 3.14-3.36\left(2 \mathrm{H}, \mathrm{m}, \mathrm{NH}-\mathrm{CH}_{2}\right), 3.50(1 \mathrm{H}, \mathrm{dt}, J 6.5,9.8 \mathrm{~Hz}, \mathrm{C} 1-$ $\mathrm{O}-\mathrm{C} \underline{\mathrm{H}}), 3.74\left(1 \mathrm{H}, \mathrm{dt}, J 6.7,9.7 \mathrm{~Hz}, \mathrm{C} 1-\mathrm{O}-\mathrm{CH}^{\prime}\right), 3.98(1 \mathrm{H}, \mathrm{s}, \mathrm{H} 2)$, $4.00(1 \mathrm{H}, \mathrm{s}, \mathrm{H} 3), 4.35(1 \mathrm{H}, \mathrm{d}, J 3.1 \mathrm{~Hz}, \mathrm{H} 4), 4.43(1 \mathrm{H}, \mathrm{d}, J 1.4 \mathrm{~Hz}$, H5), $4.96(1 \mathrm{H}, \mathrm{d}, J 4.1 \mathrm{~Hz}, \mathrm{H} 1), 6.69(1 \mathrm{H}, \mathrm{t}, J 5.9 \mathrm{~Hz}, \mathrm{NH}) ; \delta_{\mathrm{C}}$ $\left(100.61 \mathrm{MHz}, \mathrm{CDCl}_{3}\right)$ 13.91, $14.24\left(\mathrm{CH}_{3}\right), 19.43\left(\mathrm{CH}_{2} \mathrm{CH}_{3}\right), 22.81$, 27.04-32.04 $\left(\mathrm{CH}_{2}\right), 39.42\left(\mathrm{NH}-\mathrm{CH}_{2}-\right), 64.78(\mathrm{C} 2), 67.69$ (C5), $69.69\left(\mathrm{C}_{1}-\mathrm{O}-\mathrm{CH}_{2}\right), 70.54$ (C4), 71.94 (C3), 100.23 (C1), 169.68 (C6).

6ㅅ: $\delta_{\mathrm{H}}\left(400.13 \mathrm{MHz}, \mathrm{CDCl}_{3}\right) 0.86\left(3 \mathrm{H}, \mathrm{t}, \mathrm{CH}_{3}\right), 0.91\left(3 \mathrm{H}, \mathrm{t}, \mathrm{CH}_{3}\right)$, $1.24\left(18 \mathrm{H}, \mathrm{s}, \mathrm{CH}_{2}\right), 1.34-1.43\left(2 \mathrm{H}, \mathrm{m}, \mathrm{CH}_{2}\right), 1.46-1.65(4 \mathrm{H}, \mathrm{m}$, $\left.\mathrm{CH}_{2}\right)$, 3.07-3.16 (1H, m, NH-CH$), 3.28-3.37\left(1 \mathrm{H}, \mathrm{m}, \mathrm{NH}-\mathrm{CH}^{\prime}\right)$, $3.57(1 \mathrm{H}, \mathrm{dt}, J 6.7,9.5 \mathrm{~Hz}, \mathrm{C} 1-\mathrm{O}-\mathrm{CH}), 3.73(1 \mathrm{H}, \mathrm{d}, J 8.1 \mathrm{~Hz}, \mathrm{H} 2)$, $3.85\left(1 \mathrm{H}, \mathrm{dt}, J\right.$ 7.1, $\left.9.5 \mathrm{~Hz}, \mathrm{C} 1-\mathrm{O}-\mathrm{CH}^{\prime}\right), 4.15(1 \mathrm{H}, \mathrm{s}, \mathrm{H} 3), 4.19(1 \mathrm{H}$, $\mathrm{s}, \mathrm{H} 4), 4.38(1 \mathrm{H}, \mathrm{s}, \mathrm{H} 5), 4.64(1 \mathrm{H}, \mathrm{d}, J 8.0 \mathrm{~Hz}, \mathrm{H} 1), 6.83(1 \mathrm{H}, \mathrm{t}, J$ $5.8 \mathrm{~Hz}, \mathrm{NH}) ; \delta_{\mathrm{C}}\left(100.61 \mathrm{MHz}, \mathrm{CDCl}_{3}\right) 13.98,14.23\left(\mathrm{CH}_{3}\right), 19.29$ $\left(\mathrm{CH}_{2} \mathrm{CH}_{3}\right), 22.80,27.10-32.04\left(\mathrm{CH}_{2}\right), 39.44\left(\mathrm{NH}-\mathrm{CH}_{2}\right), 68.33(\mathrm{C} 2)$, 69.94 (C4), $70.03\left(\mathrm{C}_{1}-\mathrm{O}-\underline{\mathrm{C}}_{2}\right), 71.27$ (C3), 74.11 (C5), 101.04 (C1), 170.15 (C6).

8ㅅ: $\delta_{\mathrm{H}}\left(400.13 \mathrm{MHz}, \mathrm{CDCl}_{3}\right) 0.85\left(3 \mathrm{H}, \mathrm{t}, \mathrm{CH}_{3}\right), 0.90\left(3 \mathrm{H}, \mathrm{t}, \mathrm{CH}_{3}\right)$, $1.24\left(18 \mathrm{H}, \mathrm{s}, \mathrm{CH}_{2}\right), 1.28-1.36\left(2 \mathrm{H}, \mathrm{m}, \mathrm{CH}_{2}\right), 1.47-1.61(4 \mathrm{H}, \mathrm{m}$, $\left.\mathrm{CH}_{2}\right), 3.15-3.33\left(2 \mathrm{H}, \mathrm{m}, \mathrm{NH}-\mathrm{CH}_{2}\right), 3.39(1 \mathrm{H}, \mathrm{dt}, J 6.5,9.5 \mathrm{~Hz}, \mathrm{C} 1-$ O-Cㅌ), $3.61\left(1 \mathrm{H}, \mathrm{dt}, J 6.7,9.5 \mathrm{~Hz}, \mathrm{C} 1-\mathrm{O}-\mathrm{CH}^{\prime}\right), 4.04(1 \mathrm{H}, \mathrm{d}, J 4.6$ $\mathrm{Hz}, \mathrm{H} 2), 4.27(1 \mathrm{H}, \mathrm{d}, J 5.5 \mathrm{~Hz}, \mathrm{H} 4), 4.35(1 \mathrm{H}, \mathrm{d}, J 3.5 \mathrm{~Hz}, \mathrm{H} 5)$, $4.53(1 \mathrm{H}, \mathrm{s}, \mathrm{H} 3), 4.96(1 \mathrm{H}, \mathrm{s}, \mathrm{H} 1), 6.86(1 \mathrm{H}, \mathrm{t}, J 5.8 \mathrm{~Hz}, \mathrm{NH}) ; \delta_{\mathrm{C}}$ $\left(100.61 \mathrm{MHz}, \mathrm{CDCl}_{3}\right)$ 13.96, $14.26\left(\mathrm{CH}_{3}\right), 19.40\left(\mathrm{CH}_{2} \mathrm{CH}_{3}\right), 22.83$, 26.99-32.07 $\left(\mathrm{CH}_{2}\right), 39.75\left(\mathrm{NH}-\underline{\mathrm{CH}}_{2}-\right), 68.13\left(\mathrm{C}_{1}-\mathrm{O}-\underline{\mathrm{C}} \mathrm{H}_{2}\right), 70.50$ (C5), 71.76 (C3), 75.55 (C2), 80.28 (C4), 107.60 (C1), 172.15 (C6).

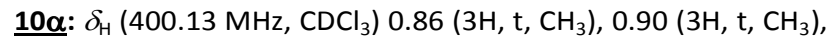
$1.23\left(18 \mathrm{H}, \mathrm{s}, \mathrm{CH}_{2}\right), 1.29-1.38\left(2 \mathrm{H}, \mathrm{m}, \mathrm{CH}_{2}\right), 1.45-1.56(4 \mathrm{H}, \mathrm{m}$, $\left.\mathrm{CH}_{2}\right)$, 3.16-3.30 (2H, m, NH-C $\left.\underline{H}_{2}\right), 3.42(1 \mathrm{H}, \mathrm{dt}, J 6.4,9.7 \mathrm{~Hz}, \mathrm{C} 1-$ $\mathrm{O}-\mathrm{CH}), 3.62\left(1 \mathrm{H}, \mathrm{dt}, J 6.5,9.7 \mathrm{~Hz}, \mathrm{C} 1-\mathrm{O}-\mathrm{CH}^{\prime}\right), 3.91(1 \mathrm{H}, \mathrm{s}, \mathrm{H} 2)$, 3.85, 3.94, $4.30(3 \mathrm{H}, \mathrm{m}, \mathrm{H} 3, \mathrm{H} 4, \mathrm{H} 5), 4.87(1 \mathrm{H}, \mathrm{d}, J 1.3 \mathrm{~Hz}, \mathrm{H} 1)$, $6.81(1 \mathrm{H}, \mathrm{t}, J 5.9 \mathrm{~Hz}, \mathrm{NH}) ; \delta_{\mathrm{C}}\left(100.61 \mathrm{MHz}, \mathrm{CDCl}_{3}\right) 13.90,14.20$ $\left(\mathrm{CH}_{3}\right), 19.39\left(\mathrm{CH}_{2} \mathrm{CH}_{3}\right), 22.77,26.95-32.00\left(\mathrm{CH}_{2}\right), 39.20(\mathrm{NH}-$ $\left.\underline{\mathrm{C}} \mathrm{H}_{2}\right), 68.21\left(\mathrm{C}_{1}-\mathrm{O}-\mathrm{CH}_{2}\right), 69.87(\mathrm{C} 2), 69.39,70.14,71.14$ (C3, C4, C5), 100.08 (C1), 171.76 (C6).

Characterization of the dodecylammonium mesylate salt. Starting with $1 \mathrm{~g}$ of alginate (1 equiv.), the quantity of this dodecyl ammonium salt formed was about 1.8 molar equiv. $(0.010 \mathrm{~mol}, 2.89 \mathrm{~g})$ as a white solid. $\mathrm{M}_{\mathrm{w}}=281.46$ requires $\mathrm{C}_{13} \mathrm{H}_{31} \mathrm{NO}_{3} \mathrm{~S}$.
$\delta_{\mathrm{H}}\left(400.13 \mathrm{MHz}, \mathrm{CDCl}_{3}-\mathrm{CD}_{3} \mathrm{OD}(1: 1 \mathrm{v} / \mathrm{v})\right): 0.88(3 \mathrm{H}, \mathrm{t}, J 6.90 \mathrm{~Hz}$, $\left.\mathrm{CH}_{3}\right)$, 1.19-1.41 (18H, m, $\left.\mathrm{CH}_{2}\right), 1.47-1.66\left(2 \mathrm{H}, \mathrm{m}, \mathrm{CH}_{2} \mathrm{CH}_{2} \mathrm{NH}_{3}{ }^{+}\right)$, $2.71\left(3 \mathrm{H}, \mathrm{s}, \mathrm{CH}_{3} \mathrm{SO}_{3}{ }^{-}\right), 2.80-2.91\left(2 \mathrm{H}, \mathrm{m}, \mathrm{CH}_{2} \mathrm{CH}_{2} \mathrm{NH}_{3}{ }^{+}\right)$.

$\delta_{\mathrm{C}}\left(100.61 \mathrm{MHz}, \mathrm{CDCl}_{3}-\mathrm{CD}_{3} \mathrm{OD}(1: 1 \mathrm{v} / \mathrm{v})\right) 14.21\left(\mathrm{CH}_{3}\right), 22.79$, $26.98,29.47,29.67,29.73,29.75,29.76,29.79,31.67$ and $32.02\left(\mathrm{CH}_{2}\right), 39.35\left(\mathrm{CH}_{2} \mathrm{CH}_{2} \mathrm{NH}_{3}{ }^{+}\right), 40.80\left(\mathrm{CH}_{3} \mathrm{SO}_{3}{ }^{-}\right)$.

- For $\mathrm{n}=18$, the crude oil was purified by silica gel chromatography (80 g, eluent $\mathrm{CH}_{2} \mathrm{Cl}_{2} / \mathrm{CH}_{3} \mathrm{OH} 95 / 5 \mathrm{v} / \mathrm{v}$ ) to provide $1.12 \mathrm{~g}(2.05 \mathrm{mmol}, 39 \%)$ of a mixture of 6 isomers named $\mathbf{A l g} \mathbf{C}_{\mathbf{4}} \mathbf{N}_{18}$ as a brown oil. This mixture is composed of: $N$-(n-octadecyl)- $n$-butyl $\alpha$-L-gulofuranosiduronamide $\underline{5 \alpha}$ (15\%), $N$-( $n$-octadecyl)- $n$-butyl $\beta$-L-gulofuranosiduronamide $\underline{\mathbf{5}}$ (25\%), $N$-( $n$-octadecyl)- $n$-butyl $\alpha$-L-gulopyranosiduronamide $\underline{7 \alpha}$ (16\%), $N$-( $n$-octadecyl)- $n$-butyl $\beta$-L-gulopyranosiduronamide $\underline{7 \beta}$ (12\%), $N$-(n-octadecyl)- $n$-butyl $\alpha$-D-mannofuranosiduronamide $\underline{9 \alpha}$ (18\%), $N$-(n-octadecyl)-n-butyl $\alpha$-D-mannopyranosiduronamide $\underline{11 \alpha}(14 \%)$ with an $\alpha / \beta$ ratio $=37 / 63$, a guluronamide pyranose/furanose ratio $=0.71$, a mannuronamide pyranose/furanose ratio $=0.84$. Man/Gul ratio $=0.46 . R f 0.47$, $0.44,0.39$ and $0.35\left(\mathrm{CH}_{2} \mathrm{Cl}_{2} / \mathrm{MeOH}: 95 / 5 \mathrm{v} / \mathrm{v}\right) . \mathrm{M}_{\mathrm{w}}=501.75$ requires $\mathrm{C}_{22} \mathrm{H}_{43} \mathrm{NO}_{6}\left(\mathrm{~m} / z(\mathrm{ESI}+)[\mathrm{M}+\mathrm{Na}]^{+}=524.2\right)$.

5 $\underline{0}: \delta_{\mathrm{H}}\left(400.13 \mathrm{MHz}, \mathrm{CDCl}_{3}\right) 0.85\left(3 \mathrm{H}, \mathrm{t}, \mathrm{CH}_{3}\right), 0.89\left(3 \mathrm{H}, \mathrm{t}, \mathrm{CH}_{3}\right)$, $1.24\left(30, \mathrm{~s}, \mathrm{CH}_{2}\right), 1.32-1.40\left(2 \mathrm{H}, \mathrm{m}, \mathrm{CH}_{2}\right), 1.46-1.56(4 \mathrm{H}, \mathrm{m}$, $\left.\mathrm{CH}_{2}\right), 3.15-3.32\left(2 \mathrm{H}, \mathrm{m}, \mathrm{NH}-\mathrm{C}_{2}\right), 3.49(1 \mathrm{H}, \mathrm{dt}, J 6.6,9.5 \mathrm{~Hz}, \mathrm{C} 1-$ $\mathrm{O}-\mathrm{C} \underline{\mathrm{H}}), 3.61\left(1 \mathrm{H}, \mathrm{dt}, J 6.8,9.2 \mathrm{~Hz}, \mathrm{C} 1-\mathrm{O}-\mathrm{CH}^{\prime}\right), 4.09(1 \mathrm{H}, \mathrm{s}, \mathrm{H} 2)$, $4.28(1 \mathrm{H}, \mathrm{s}, \mathrm{H} 4), 4.31(1 \mathrm{H}, \mathrm{s}, \mathrm{H} 3), 4.37(1 \mathrm{H}, \mathrm{d}, J 4.4 \mathrm{~Hz}, \mathrm{H} 5), 4.96$ $(1 \mathrm{H}, \mathrm{d}, J 4.7 \mathrm{~Hz}, \mathrm{H} 1), 6.80(1 \mathrm{H}, \mathrm{t}, J 5.9 \mathrm{~Hz}, \mathrm{NH}) ; \delta_{\mathrm{C}}(100.61 \mathrm{MHz}$, $\left.\mathrm{CDCl}_{3}\right)$ 13.96, $14.22\left(\mathrm{CH}_{3}\right), 19.41\left(\mathrm{CH}_{2} \mathrm{CH}_{3}\right), 22.80,27.02-32.01$ $\left(\mathrm{CH}_{2}\right), 39.54\left(\mathrm{NH}-\underline{\mathrm{C}} \mathrm{H}_{2}\right), 69.31\left(\mathrm{C}_{1}-\mathrm{O}-\underline{\mathrm{CH}}_{2}\right), 70.93$ (C3), 71.17 (C5), 72.54 (C2), 80.83 (C4), 101.76 (C1), 171.47 (C6).

표: $\delta_{\mathrm{H}}\left(400.13 \mathrm{MHz}, \mathrm{CDCl}_{3}\right) 0.87\left(3 \mathrm{H}, \mathrm{t}, \mathrm{CH}_{3}\right), 0.92\left(3 \mathrm{H}, \mathrm{m}, \mathrm{CH}_{3}\right)$, $1.24\left(30 \mathrm{H}, \mathrm{s}, \mathrm{CH}_{2}\right), 1.35-1.40\left(2 \mathrm{H}, \mathrm{m}, \mathrm{CH}_{2}\right), 1.46-1.57(4 \mathrm{H}, \mathrm{m}$, $\left.\mathrm{CH}_{2}\right), 3.19-3.31\left(2 \mathrm{H}, \mathrm{m}, \mathrm{NH}-\mathrm{CH}_{2}\right), 3.37(1 \mathrm{H}, \mathrm{dt}, J 6.6,9.6 \mathrm{~Hz}, \mathrm{C} 1-$ $\mathrm{O}-\mathrm{C} \underline{\mathrm{H}}), 3.63\left(1 \mathrm{H}, \mathrm{dt}, J 6.7,9.7 \mathrm{~Hz}, \mathrm{C} 1-\mathrm{O}-\mathrm{CH}^{\prime}\right), 4.04(1 \mathrm{H}, \mathrm{d}, J 4.7$ $\mathrm{Hz}, \mathrm{H} 2), 4.30(1 \mathrm{H}, \mathrm{dd}, J 4.0,7.0 \mathrm{~Hz}, \mathrm{H} 4), 4.34(1 \mathrm{H}, \mathrm{d}, J 4.6 \mathrm{~Hz}$, $\mathrm{H} 5), 4.58(1 \mathrm{H}, \mathrm{d}, J 5.9 \mathrm{~Hz}, \mathrm{H} 3), 4.94(1 \mathrm{H}, \mathrm{s}, \mathrm{H} 1), 7.01(1 \mathrm{H}, \mathrm{t}, J 5.9$ $\mathrm{Hz}, \mathrm{NH}) ; \delta_{\mathrm{C}}\left(100.61 \mathrm{MHz}, \mathrm{CDCl}_{3}\right) 13.95,14.25\left(\mathrm{CH}_{3}\right), 19.35$ $\left(\mathrm{CH}_{2} \mathrm{CH}_{3}\right), 22.82,26.98-32.05\left(\mathrm{CH}_{2}\right), 39.47\left(\mathrm{NH}-\mathrm{CH}_{2}\right), 67.84\left(\mathrm{C}_{1^{-}}\right.$ $\mathrm{O}-\mathrm{CH}_{2}$ ), 70.22 (C5), 71.02 (C3), 74.91 (C2), 79.91 (C4), 106.46 (C1), 172.35 (C6).

7 $\alpha$ : $\delta_{\mathrm{H}}\left(400.13 \mathrm{MHz}, \mathrm{CDCl}_{3}\right) 0.86\left(3 \mathrm{H}, \mathrm{t}, \mathrm{CH}_{3}\right), 0.92\left(3 \mathrm{H}, \mathrm{t}, \mathrm{CH}_{3}\right)$, $1.24\left(30 \mathrm{H}, \mathrm{s}, \mathrm{CH}_{2}\right), 1.32-1.40\left(2 \mathrm{H}, \mathrm{m}, \mathrm{CH}_{2}\right), 1.46-1.64(4 \mathrm{H}, \mathrm{m}$, $\left.\mathrm{CH}_{2}\right)$, 3.19-3.37 (2H, m, NH-C $\left.\underline{\mathrm{H}}_{2}\right), 3.49(1 \mathrm{H}, \mathrm{dt}, J$ 6.6, $9.9 \mathrm{~Hz}, \mathrm{C} 1-$ $\left.\mathrm{O}-\mathrm{C} \underline{\mathrm{H}}), 3.73\left(1 \mathrm{H}, \mathrm{dt}, J 6.7,9.7 \mathrm{~Hz}, \mathrm{C} 1-\mathrm{O}-\mathrm{C}^{\prime}\right)^{\prime}\right), 3.98(1 \mathrm{H}, \mathrm{d}, J 4.2$ $\mathrm{Hz}, \mathrm{H} 2), 4.02(1 \mathrm{H}, \mathrm{s}, \mathrm{H} 3), 4.32(1 \mathrm{H}, \mathrm{d}, J 6.8 \mathrm{~Hz}, \mathrm{H} 4), 4.43(1 \mathrm{H}, \mathrm{d}, J$ $1.3 \mathrm{~Hz}, \mathrm{H} 5), 4.96(1 \mathrm{H}, \mathrm{d}, J 3.5 \mathrm{~Hz}, \mathrm{H} 1), 6.73(1 \mathrm{H}, \mathrm{t}, J 5.9 \mathrm{~Hz}, \mathrm{NH})$; $\delta_{\mathrm{C}}\left(100.61 \mathrm{MHz}, \mathrm{CDCl}_{3}\right) 13.91,14.24\left(\mathrm{CH}_{3}\right), 19.41\left(\mathrm{CH}_{2} \mathrm{CH}_{3}\right)$, 22.81, 26.98-32.05 $\left(\mathrm{CH}_{2}\right), 39.44\left(\mathrm{NH}-\mathrm{CH}_{2}\right), 64.74(\mathrm{C} 2), 67.64$ (C5), $69.66\left(\mathrm{C}_{1}-\mathrm{O}-\mathrm{CH}_{2}\right), 70.47$ (C4), 71.84 (C3), 100.15 (C1), 169.92 (C6).

7ㅍ: $\delta_{\mathrm{H}}\left(400.13 \mathrm{MHz}, \mathrm{CDCl}_{3}\right) 0.87\left(3 \mathrm{H}, \mathrm{t}, \mathrm{CH}_{3}\right), 0.92\left(3 \mathrm{H}, \mathrm{t}, \mathrm{CH}_{3}\right)$, $1.24\left(30 \mathrm{H}, \mathrm{s}, \mathrm{CH}_{2}\right), 1.35-1.44\left(2 \mathrm{H}, \mathrm{m}, \mathrm{CH}_{2}\right), 1.46-1.64(4 \mathrm{H}, \mathrm{m}$, $\left.\mathrm{CH}_{2}\right)$, 3.10-3.19 (1H, m, NH-C$), 3.28-3.39\left(1 \mathrm{H}, \mathrm{m}, \mathrm{NH}-\mathrm{CH}^{\prime}\right)$, $3.57(1 \mathrm{H}, \mathrm{dt}, J 6.8,9.7 \mathrm{~Hz}, \mathrm{C} 1-\mathrm{O}-\mathrm{CH}), 3.73(1 \mathrm{H}, \mathrm{dd}, J 2.6,7.9 \mathrm{~Hz}$, $\mathrm{H} 2), 3.86\left(1 \mathrm{H}, \mathrm{dt}, J 6.8,9.7 \mathrm{~Hz}, \mathrm{C} 1-\mathrm{O}-\mathrm{CH}^{\prime}\right), 4.17(1 \mathrm{H}, \mathrm{d}, J 4.5 \mathrm{~Hz}$, H3), $4.20(1 \mathrm{H}, \mathrm{s}, \mathrm{H} 4), 4.38(1 \mathrm{H}, \mathrm{s}, \mathrm{H} 5), 4.64(1 \mathrm{H}, \mathrm{d}, J 8.1 \mathrm{~Hz}, \mathrm{H} 1)$, 
$6.80(1 \mathrm{H}, \mathrm{t}, J 5.9 \mathrm{~Hz}, \mathrm{NH}) ; \delta_{\mathrm{C}}\left(100.61 \mathrm{MHz}, \mathrm{CDCl}_{3}\right) 13.99,14.25$ $\left(\mathrm{CH}_{3}\right), 19.30\left(\mathrm{CH}_{2} \mathrm{CH}_{3}\right), 22.82,27.11-32.04\left(\mathrm{CH}_{2}\right), 39.44(\mathrm{NH}-$ $\left.\mathrm{CH}_{2}\right), 68.36(\mathrm{C} 2), 69.89(\mathrm{C} 4), 70.06\left(\mathrm{C}_{1}-\mathrm{O}-\underline{\mathrm{CH}}_{2}\right), 71.20(\mathrm{C} 3), 74.14$ (C5), 101.05 (C1), 170.10 (C6).

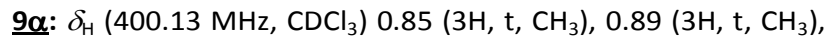
$1.24\left(30 \mathrm{H}, \mathrm{s}, \mathrm{CH}_{2}\right), 1.32-1.40\left(2 \mathrm{H}, \mathrm{m}, \mathrm{CH}_{2}\right), 1.46-1.56(4 \mathrm{H}, \mathrm{m}$, $\left.\mathrm{CH}_{2}\right), 3.15-3.32\left(2 \mathrm{H}, \mathrm{m}, \mathrm{NH}-\mathrm{CH}_{2}\right), 3.38(1 \mathrm{H}, \mathrm{dt}, J 6.5,9.6 \mathrm{~Hz}, \mathrm{C} 1-$ $\left.\mathrm{O}-\mathrm{C} \underline{\mathrm{H}}), 3.61\left(1 \mathrm{H}, \mathrm{dt}, J 6.8,9.2 \mathrm{~Hz}, \mathrm{C} 1-\mathrm{O}-\mathrm{C}^{\prime}\right)^{\prime}\right), 4.01(1 \mathrm{H}, \mathrm{d}, J 4.8$ $\mathrm{Hz}, \mathrm{H} 2), 4.32(1 \mathrm{H}, \mathrm{d}, J 4.8 \mathrm{~Hz}, \mathrm{H} 4), 4.37(1 \mathrm{H}, \mathrm{d}, J 4.4 \mathrm{~Hz}, \mathrm{H} 5)$, $4.50(1 \mathrm{H}, \mathrm{s}, \mathrm{H} 3), 4.94(1 \mathrm{H}, \mathrm{s}, \mathrm{H} 1), 7.00(1 \mathrm{H}, \mathrm{t}, J 5.5 \mathrm{~Hz}, \mathrm{NH}) ; \delta_{\mathrm{C}}$ $\left(100.61 \mathrm{MHz}, \mathrm{CDCl}_{3}\right) 13.93,14.22\left(\mathrm{CH}_{3}\right), 19.36\left(\mathrm{CH}_{2} \mathrm{CH}_{3}\right), 22.80$, 27.00-32.03 $\left(\mathrm{CH}_{2}\right), 39.64\left(\mathrm{NH}-\underline{\mathrm{C}} \mathrm{H}_{2}\right), 68.03\left(\mathrm{C}_{1}-\mathrm{O}-\underline{\mathrm{CH}_{2}}\right), 70.55$ (C5), 71.72 (C3), 75.52 (C2), 80.32 (C4), 107.42 (C1), 172.39 (C6).

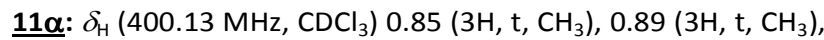
$1.24\left(30 \mathrm{H}, \mathrm{s}, \mathrm{CH}_{2}\right), 1.32-1.40\left(2 \mathrm{H}, \mathrm{m}, \mathrm{CH}_{2}\right), 1.46-1.56(4 \mathrm{H}, \mathrm{m}$, $\left.\mathrm{CH}_{2}\right), 3.15-3.32\left(2 \mathrm{H}, \mathrm{m}, \mathrm{NH}-\mathrm{CH}_{2}\right), 3.38(1 \mathrm{H}, \mathrm{dt}, J 6.5,9.6 \mathrm{~Hz}, \mathrm{C} 1-$ $\mathrm{O}-\mathrm{C} \underline{\mathrm{H}}), 3.61\left(1 \mathrm{H}, \mathrm{dt}, J 6.8,9.2 \mathrm{~Hz}, \mathrm{C} 1-\mathrm{O}-\mathrm{CH}^{\prime}\right), 3.92(1 \mathrm{H}, \mathrm{s}, \mathrm{H} 2)$, 3.86, 3.94, $4.31(3 \mathrm{H}, \mathrm{m}, \mathrm{H} 3, \mathrm{H} 4, \mathrm{H} 5), 4.89(1 \mathrm{H}, \mathrm{d}, J 1.5 \mathrm{~Hz}, \mathrm{H} 1)$, $6.88(1 \mathrm{H}, \mathrm{t}, J 5.9 \mathrm{~Hz}, \mathrm{NH}) ; \delta_{\mathrm{C}}\left(100.61 \mathrm{MHz}, \mathrm{CDCl}_{3}\right) 13.96,14.22$ $\left(\mathrm{CH}_{3}\right), 19.38\left(\mathrm{CH}_{2} \mathrm{CH}_{3}\right), 22.80,26.97-32.03\left(\mathrm{CH}_{2}\right), 39.22(\mathrm{NH}-$ $\left.\mathrm{CH}_{2}\right), 68.37\left(\mathrm{C}_{1}-\mathrm{O}-\underline{\mathrm{CH}}_{2}\right), 69.92(\mathrm{C} 2), 69.27,70.14,71.04$ (C3, C4, C5), 100.04 (C1), 171.88 (C6).

Characterization of the octadecylammonium mesylate salt. Starting with $1 \mathrm{~g}$ of alginate (1 equiv.), the quantity of this octadecyl ammonium salt formed was about 2 molar equiv. ( $0.011 \mathrm{~mol}, 4.16 \mathrm{~g})$ as a white solid. $\mathrm{M}_{\mathrm{w}}=365.62$ requires $\mathrm{C}_{19} \mathrm{H}_{43} \mathrm{NO}_{3} \mathrm{~S}$.

$\delta_{\mathrm{H}}\left(400.13 \mathrm{MHz}, \mathrm{CDCl}_{3}-\mathrm{CD}_{3} \mathrm{OD}(1: 1 \mathrm{v} / \mathrm{v})\right) 0.89(3 \mathrm{H}, \mathrm{t}, J 7.1 \mathrm{~Hz}$, $\left.\mathrm{CH}_{3}\right), 1.24-1.38\left(30 \mathrm{H}, \mathrm{m}, \mathrm{CH}_{2}\right), 1.61-1.69\left(2 \mathrm{H}, \mathrm{m}, \mathrm{CH}_{2} \mathrm{CH}_{2} \mathrm{NH}_{3}{ }^{+}\right)$, $2.71\left(3 \mathrm{H}, \mathrm{s}, \mathrm{CH}_{3} \mathrm{SO}_{3}{ }^{-}\right), 2.85-2.93\left(2 \mathrm{H}, \mathrm{m}, \mathrm{CH}_{2} \mathrm{CH}_{2} \mathrm{NH}_{3}{ }^{+}\right)$.

$\delta_{\mathrm{C}}\left(100.61 \mathrm{MHz}, \mathrm{CDCl}_{3}-\mathrm{CD}_{3} \mathrm{OD}(1: 1 \mathrm{v} / \mathrm{v})\right) 14.43\left(\mathrm{CH}_{3}\right), 23.60$, 27.35, 28.43, 30.10, 30.33, 30.38, 30.52, 30.61, 30.64, 32.92 $\left(\mathrm{CH}_{2}\right), 39.42\left(\mathrm{CH}_{2} \mathrm{CH}_{2} \mathrm{NH}_{3}^{+}\right), 40.67\left(\underline{\mathrm{C}} \mathrm{H}_{3} \mathrm{SO}_{3}{ }^{-}\right)$.

Direct process to synthesize alkyl-L-guluronamides and alkylD-mannuronamides monosaccharide from alginate (with previous neutralization of the medium before aminolysis reaction)

Step 1 - Butanolysis and Fischer glycosylation. Sodium alginate $1(110200 \mathrm{~g} / \mathrm{mol}, \mathrm{DP}=630)$ which $\mathrm{M} / \mathrm{G}$ ratio is about 0.78 (5.71 mmol, 1 equiv., $1 \mathrm{~g}$ ) was mixed with $3 \mathrm{~mL}$ of deionized water and $927 \mu \mathrm{L}$ of methane sulfonic acid (14.27 mmol, 2.5 equiv.). $80 \mathrm{~mL}$ of $\mathrm{BuOH}$ (150 equiv.) were then added to the solution of alginate. In refluxing butanol (130$135^{\circ} \mathrm{C}$ ), the mixture was vigorously stirred for $24 \mathrm{~h}$. Water present in the medium and formed during the glycosylation and esterification reactions was progressively eliminated in a Dean Stark material filled with butanol by azeotropic evaporation $\left(\mathrm{H}_{2} \mathrm{O} / \mathrm{BuOH}\right)$. After $24 \mathrm{~h}$, the reaction mixture was allowed to cool down to room temperature, then a thin layer chromatography $\left(\mathrm{CH}_{2} \mathrm{Cl}_{2} / \mathrm{CH}_{3} \mathrm{OH} 95 / 5 \mathrm{v} / \mathrm{v}\right)$ and ${ }^{1} \mathrm{H}$ and ${ }^{13} \mathrm{C} \mathrm{NMR}$ experiments $\left(\mathrm{CDCl}_{3}\right)$ were carried out for the medium to ensure that the expected products were synthesized

Step 2 - Neutralization of the reaction medium. In order to reduce the quantity of fatty amine added during the second step of the process, the reaction medium was neutralized until $\mathrm{pH} 7$, after cooling at $60^{\circ} \mathrm{C}$, with aq. $1 \mathrm{~N} \mathrm{NaOH}(8 \mathrm{~mL})$. The reaction medium was then partly concentrated before adding the fatty amine.

Step 3 - Aminolysis reaction. Dodecylamine $(5.71 \mathrm{mmol}, 1$ equiv., $1.06 \mathrm{~g}$ ) was added to the reaction medium. The medium was homogenized at $65^{\circ} \mathrm{C}$ and under vacuum (150 mbar) for 30 min.; $\mathrm{BuOH}$ was evaporated by reducing the pressure, progressively, to 6 mbar. The reaction medium was stirred at $65^{\circ} \mathrm{C}$ for 1 hour and a half under vacuum (6 mbar) until $\mathrm{BuOH}$ gas evolution stopped.

Water (60 mL, 500 equiv.) was then added and the mixture was vigorously stirred at $70^{\circ} \mathrm{C}$ for 15 minutes. Organic products flocculate at the surface of water. After cooling the reaction medium at room temperature, the organic phase solidifies and it will be easy, at this stage, to remove the salt-containing aqueous phase and solid flocculates were recovered. The crude brown oil named crude $\mathrm{AlgC}_{4} \mathbf{N}_{12}$ isolated in $1.21 \mathrm{~g}(2.9$ mmol) consists mainly of dodecyl ammonium salt in addition to the 6 isomers of $\mathrm{C}_{22} \mathrm{H}_{43} \mathrm{NO}_{6}(\mathrm{Mw}=417.59 \mathrm{~g} / \mathrm{mol}): \mathrm{N}-(n-$ dodecyl)- $n$-butyl $\alpha$-L-gulofuranosiduronamide $\underline{4 \alpha}(14 \%), N$ - $(n$ dodecyl)- $n$-butyl $\beta$-L-gulofuranosiduronamide $\underline{4 \beta}(24 \%), N$ - $(n-$ dodecyl)-n-butyl $\alpha$-L-gulopyranosiduronamide $\underline{\mathbf{6} \alpha}(18 \%), N$ - $(n$ dodecyl)- $n$-butyl $\beta$-L-gulopyranosiduronamide $\underline{6} \boldsymbol{\beta}(10 \%), N$ - $(n$ dodecyl)- $n$-butyl $\alpha$-D-mannofuranosiduronamide $\underline{8 \alpha}$ (19\%), $N$ (n-dodecyl)-n-butyl $\alpha$-D-mannopyranosiduronamide $\quad \underline{10 \alpha}$ (15\%); Gul pyranose/furanose ratio $=0.73$; Man pyranose $/$ furanose $=0.79 ; \alpha / \beta$ ratio $=34 / 66 ;$ Man $/$ Gul ratio (0.51).

Crude $\operatorname{AlgC}_{4} \mathrm{~N}_{12}: \delta_{\mathrm{H}}\left(400.13 \mathrm{MHz}, \mathrm{CDCl}_{3}\right) 0.87\left(\mathrm{t}, \mathrm{CH}_{3}\right), 0.92\left(\mathrm{t}, \mathrm{CH}_{3}\right)$; $1.24\left(\mathrm{~s}, \mathrm{CH}_{2}\right) ; 1.30-1.36\left(\mathrm{~m}, \mathrm{NHCH}_{2} \mathrm{CH}_{2}\right) ; 1.40-1.48\left(\mathrm{~m}, \mathrm{OCH}_{2} \mathrm{CH}_{2} \mathrm{CH}_{2}\right)$; 1.49-1.57 (m, $\left.2 \mathrm{H}, \mathrm{CH}_{2} \mathrm{CH}_{2} \mathrm{NH}_{3}{ }^{+}\right) ; 2.69\left(\mathrm{~s}, 3 \mathrm{H}, \mathrm{CH}_{3} \mathrm{SO}_{3}{ }^{-}\right) ; 2.73-2.86(\mathrm{~m}$, $\left.2 \mathrm{H}, \mathrm{CH}_{2} \mathrm{CH}_{2} \mathrm{NH}_{3}{ }^{+}\right) ; 3.18-3.36\left(12 \mathrm{H}, \mathrm{m}, 6 \times \mathrm{NHCH}_{2}\right) ; 3.43(6 \mathrm{H}, \mathrm{dt}, J 6.2$, $9.8 \mathrm{~Hz}, \mathrm{OCH} \underline{\mathrm{H}}) ; 3.64(6 \mathrm{H}, \mathrm{dt}, J 6.7,9.6 \mathrm{~Hz}, \mathrm{OC} \underline{\mathrm{H}} \mathrm{H}) ; 3.74,3.92,3.98$, 4.04, $4.12(6 \mathrm{H}, \mathrm{H} 2) ; 3.85,4.01,4.16,4.33,4.51,4.62(6 \mathrm{H}, \mathrm{H} 3) ; 3.97$, $4.26,4.27,4.20,4.31(6 \mathrm{H}, \mathrm{H} 4)$; 4.29-4.45 (6H, H5); $4.64(1 \mathrm{H}, \mathrm{d}, J 8.0$ $\mathrm{Hz}, \mathrm{H} 1$ of $\underline{6 \beta}) ; 4.88(1 \mathrm{H}, \mathrm{d}, J 1.5 \mathrm{~Hz}, \mathrm{H} 1$ of $\underline{\mathbf{1 0 \alpha}}) ; 4.94(1 \mathrm{H}, \mathrm{s}, \mathrm{H} 1$ of $\underline{8 \alpha})$; $4.95(\mathrm{~s}, 1 \mathrm{H}, \mathrm{H}-1$ of $\underline{\mathbf{\beta}})$; $4.96(1 \mathrm{H}, \mathrm{d}, J 4.5 \mathrm{~Hz}, \mathrm{H} 1$ of $\underline{4 \alpha}) ; 4.97(1 \mathrm{H}, \mathrm{d}, J$ $4.2 \mathrm{~Hz}, \mathrm{C}-1$ of $\underline{6 \alpha}) ; 6.72,6.74,6.80,6.86,6.96,7.01(6 \mathrm{H}, \mathrm{t}, J 5.9 \mathrm{~Hz}, 6 \mathrm{x}$ $\mathrm{NH}) ; \delta_{1 \mathrm{C}}\left(100.61 \mathrm{MHz}, \mathrm{CDCl}_{3}\right): 13.94,14.21\left(\mathrm{CH}_{3}\right) ; 19.33\left(\mathrm{CH}_{2} \mathrm{CH}_{3}\right)$; 22.79, 26.98, 29.41-29.79, 31.58, 31.77, $32.02\left(\mathrm{CH}_{2}\right) ; 39.32-39.54$ (6 $\left.x \mathrm{NH}_{\mathrm{CH}}\right) ; 39.41\left(\mathrm{CH}_{2} \mathrm{CH}_{2} \mathrm{NH}_{3}{ }^{+}\right) ; 40.86\left(\mathrm{CH}_{3} \mathrm{SO}_{3}{ }^{-}\right) ; 67.62,68.05,68.2$, $69.04,69.17,69.67\left(6 \times \mathrm{OCH}_{2}\right) ; 64.75,68.22,69.67,72.59,74.50$, 75.67 ( 6 x C2); 70.56, 70.65, 71.14, 71.18, 71.64, 71.76 (6 x C3); $68.60,69.83,70.56,79.67,80.46,81.30$ (6* C4); 67.67, 69.93, 70.57, $71.26,71.40,74.51$ ( $6 \times C 5) ; 100.04$ (C1 of $\underline{10 \alpha}$ ); 100.39 (C1 of $\underline{6 \alpha}$ ); 101.41 (C1 of $\underline{\mathbf{6} \beta}$ ); 101.76 (C1 of $\underline{\mathbf{4 \alpha}}$ ); 106.28 (C1 of $\underline{\mathbf{4}}$ ); 107.55 (C-1 of $8 \alpha$ ); 169.91, 170.13, 171.60, 171.65, 172.63, 172.67 (6 x C-6).

According to the analysis of $1 \mathrm{D}$ and $2 \mathrm{D}$ NMR spectra of crude AlgC $\mathrm{C}_{4} \mathrm{~N}_{12}$, dodecyl ammonium salts formed during the aminolysis reaction were quantified. Starting with $1 \mathrm{~g}$ of alginate (1 equiv.), the amount formed was about 0.4 equiv. ( 0.0023 moles, $0.64 \mathrm{~g}$ ). 
Evaluation of the interfacial tension (case of sunflower oil-water system). Interfacial properties of monosaccharide surfactant compositions GulC $\mathbf{N}_{12}$, GulC $_{4} \mathrm{~N}_{18}, \operatorname{AlgC}_{4} \mathrm{~N}_{12}, \operatorname{AlgC}_{4} \mathrm{~N}_{18}$ and crude $A \lg C_{4} N_{12}$ were evaluated by measuring interfacial tension at the oil/water interface. Monosaccharide surfactants were dissolved in sunflower oil, over a range of surfactant concentrations varying from 0.12 to $2.28 \mathrm{~g} / \mathrm{L}$. Solutions were left in ultrasonic bath for 10 minutes at $50^{\circ} \mathrm{C}$ to well dissolve surfactants in oil. Solutions were aged for at least 24 hours at $25^{\circ} \mathrm{C}$ before the measurement. Interfacial tension between sunflower oil and water at $25^{\circ} \mathrm{C}$ varied between 24.71 and $25.04 \mathrm{mN} / \mathrm{m}$.

For each surfactant composition, the apparatus (tensiometer Krüss, K100, Du Noüy ring method) measured initially the surface tension of sunflower oil containing the surfactant (low density liquid), then the surface tension of water (high density liquid). Finally, the oil was gently added on the surface of water, avoiding the formation of bubbles; the apparatus started to measure about 10 times the interfacial tension at the interface between oil and water with 2 minutes interval between each reading.

Evaluation of the emulsifying properties. The stability of oil-inwater $(\mathrm{O} / \mathrm{W})$ and water-in-oil $(\mathrm{W} / \mathrm{O})$ emulsions formed from monosaccharide surfactant compositions $\mathbf{G u l C}_{4} \mathbf{N}_{12}, \mathbf{G u l C}_{4} \mathbf{N}_{18}$,

$A_{\lg } \mathrm{C}_{4} \mathrm{~N}_{12}, \mathrm{AlgC}_{4} \mathrm{~N}_{18}$ and crude $\mathrm{AlgC}_{4} \mathbf{N}_{12}$ was studied in comparison with that of commercial alkylpolyglycosides: Montanov 82 from Seppic and Xyliance from Soliance/ARD.

The stability of the two types of emulsions $\mathrm{O} / \mathrm{W}$ and $\mathrm{W} / \mathrm{O}$ was evaluated, by considering the two ratios water/oil 75/25 and $25 / 75$, respectively. In round-bottom tubes clearly graduated, $0.5 \%$ of surfactant product was introduced $(20 \mathrm{mg})$. Then, sunflower oil was added ( 1 or $3 \mathrm{~mL}$ ) and surfactants were dissolved in ultrasonic bath for 10 minutes at $50^{\circ} \mathrm{C}$. Thereafter, deionized water was added in the tubes ( 1 or $3 \mathrm{~mL}$ ). Both phases were then emulsified using a homogenizer Ultraturrax Ika T18 basic $^{\circledR}$ for 10 minutes at $11000 \mathrm{rpm}$. After that, the emulsion was placed in a thermostatic bath at $20^{\circ} \mathrm{C}$. The evolution of the emulsion and its gradual phase separation was observed for a few hours to several weeks.

\section{Acknowledgments}

The AZM \& SAADE association and the doctoral school for sciences and technology-Lebanese university are acknowledged for their financial support.

\section{Notes and references}

1 (a) C. C. Ruiz, Editor, Sugar-based Surfactants : fundamentals and applications In Surfactant Science Series, CRC Press Taylor \& Francis Group, vol.143, 2009; (b) P. Foley, A.
Kermanshah, E. S. Beach, J. B. Zimmerman, Chem. Soc. Rev. 2012, 41, 1499-1518; (c) W. von Rybinski, K. Hill, Angew. Chem., 1998, 110, 1394-1412; Angew. Chem. Int. Ed., 1998, 37, 1328-1345.

2 (a) P. Laurent, H. Razafindralambo, B. Wathelet, C. Blecker, J.-P. Wathelet, M. Paquot, J. Surfactants Deterg., 2011, 14, 51-63; (b) T. Benvegnu, D. Plusquellec, M. Roussel. FR 2840306, WO 2003104248, 2003; (c) T. Benvegnu and J.-F. Sassi, in Carbohydrates in sustainable development. I. Renewable Resources for Chemistry and Biotechnology. Edited by A. P. Rauter, P. Vogel, Y. Queneau, 2010, 294, 143164; (d) M. Roussel, T. Benvegnu, V. Lognoné, H. Le Deit, I. Soutrel, I. Laurent, D. PLusquellec, Eur. J. Org. Chem., 2005, 3085-3094; (e) F. Vallée, C. Müller, A. Durand, S. Schimchowitsch, E. Dellacherie, C. Kelche, J.-C. Cassel, M. Leonard, Carbohydr. Res., 2009, 344, 223-228.

3 R. H. Beck, N. J. Kalff, and H. W. W. Roper, European Patent Application, EP 536939, 1993.

4 V. Au, B. Harichian, A. Hung, and R. Vermeer, US 5872111 A, 1999.

5 J. J. Scheibel, D. S. Connor, R. E. Shumate, and L. J. Charles, PCT Int Appl. WO 92 06984, assigned to Protector and Gamble, 1992

6 C. L. Mehltretter, R. L. Mellies, and J. C. Rankin, US patent 2670345, Assigned to US Dept. of Agriculture, 1954.

7 Z. Wang. United States patent US 7655611 B2, 2010

8 (a) N. Villandier, A. Corma, Chem. Commun., 2010, 46, 44084410 ; (b) N. Villandier, A. Corma, ChemSusChem, 2011, 4 508-513.

9 (a) A. Ignatyev, P. G. N. Mertens, C. V. Doorslaer, K. Binnemans, D. E. de Vos, Green Chem., 2010, 12, 1790-1795; (b) M. Sekine, T. Kimura, Y. Katayama, D. Takahashi, K. Toshima, RSC Adv., 2013, 3, 19756-19759.

10 N. Sari-Chmayssem, S. Taha, H. Mawlawi, J. P. Guégan, J. Jeftić, T. Benvegnu, J. Appl. Phycol., 2016, 28, 1915-1929.

11 I. Macher, K. Dax, H. Inselsbacher, H. Weidmann, Carbohydr. Res., 1979, 77, 225-230.

12 (a) J. Dinkelaar, L. J. Van Den Bos, W. F. J. Hogendorf, G. Lodder, H. S. Overkleeft, J. D. C. Codée, G. A. Van Der Marel, Chem. Eur. J., 2008, 14, 9400-9411; (b) T. Anthonsen, M. A. E. Sallam, Carbohydr. Res., 1980, 78, 368-371; (c) R. C. N. Reis, S. C. Oda, M. V. De Almeida, M. C. S. Lourenço, F. R. C. Vicente, N. R. Barbosa, R. Trevizani, P. L. C. Santos, M. Le Hyaric, J. Brazilian Chem. Soc., 2008, 19, 1065-1072.

13 S. S. Nigudkar, A. V. Demchenko, Chem. Sci., 2015, 6, $2687-$ 2704.

14 K Lunkenheimer, K.D Wantke, J. Colloid Interface Sci., 1978, 66, 579-581. 
One-pot transformation of L-polyguluronate or alginate into $100 \%$ bio-based surfactants proceeded efficiently to provide novel long-chain alkyl-L-guluronamide/D-mannuronamide compositions as emulsion stabilizers.

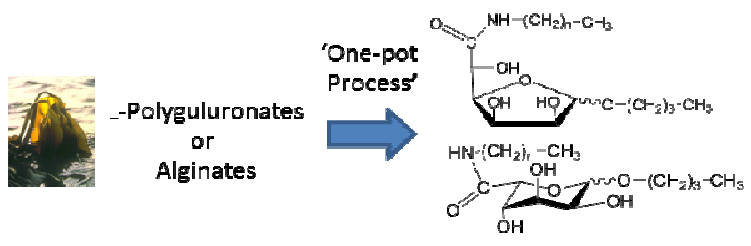

